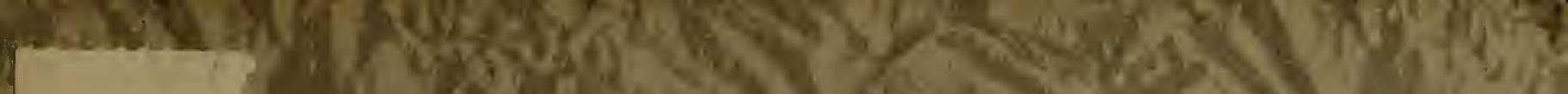

NE

260

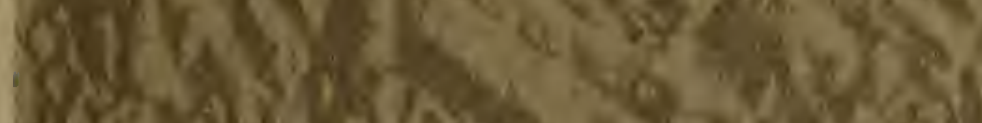

S64

NPG

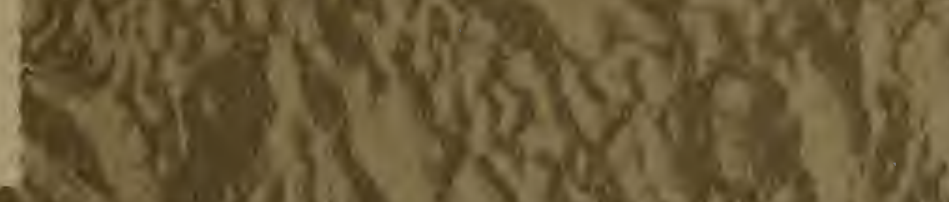

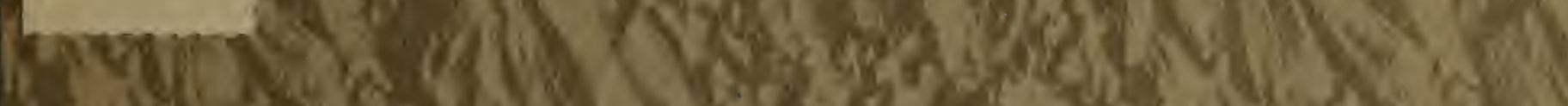

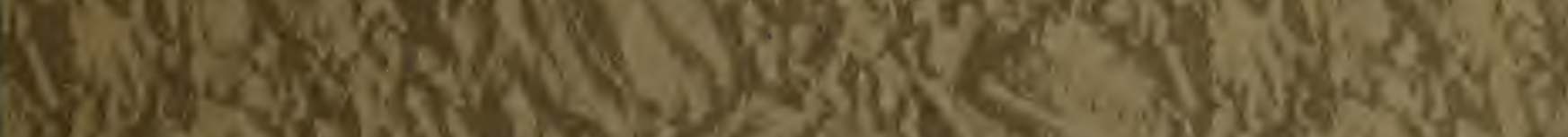

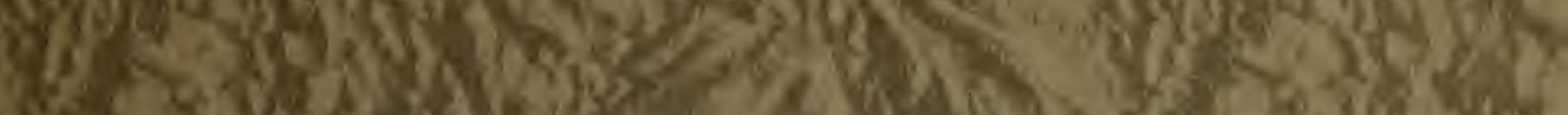
W.

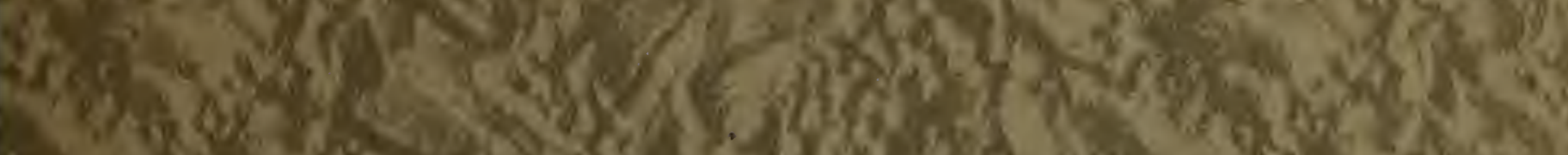

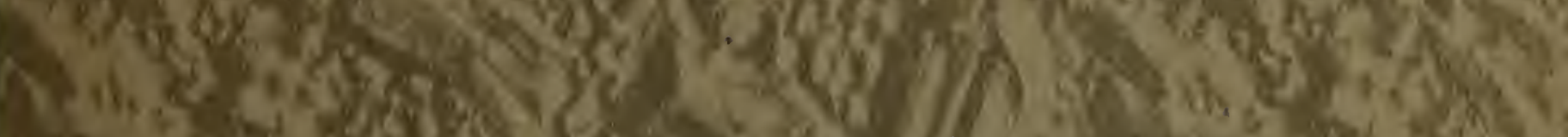

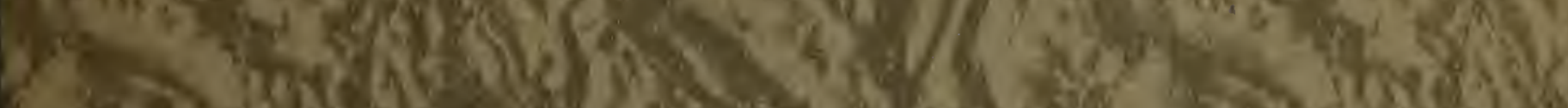
Kats

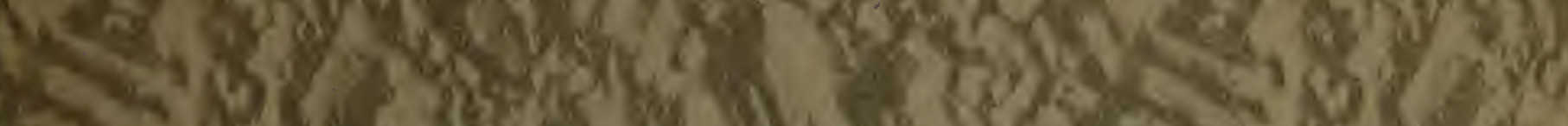

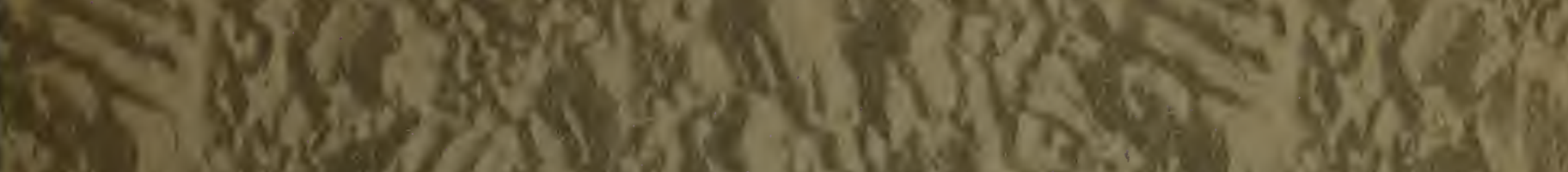

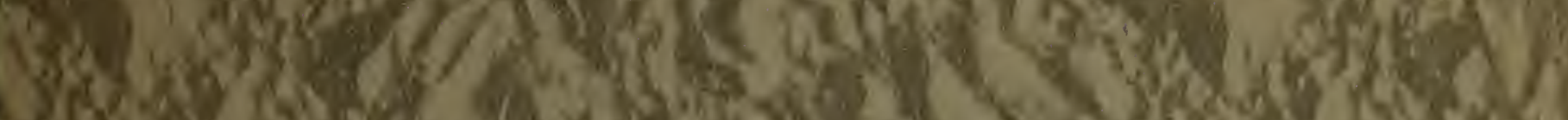

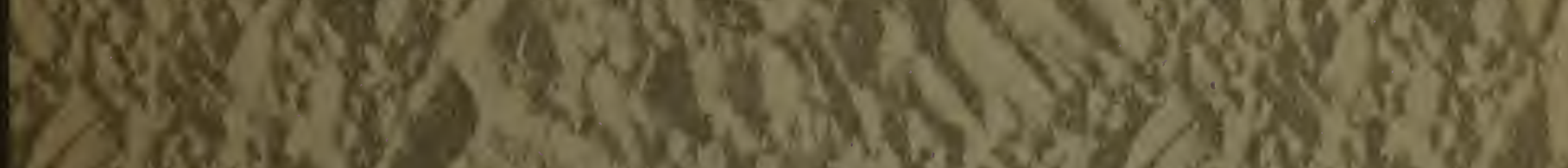

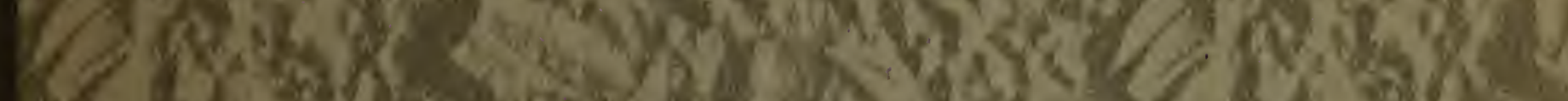

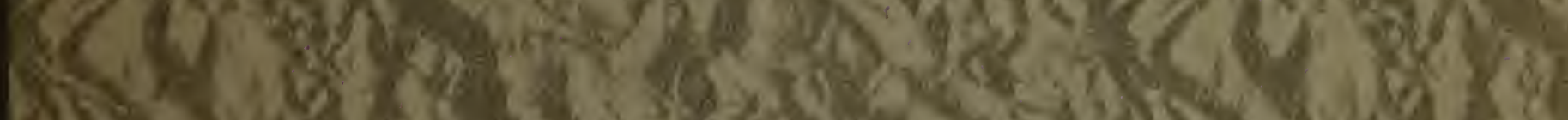
Q6. W.

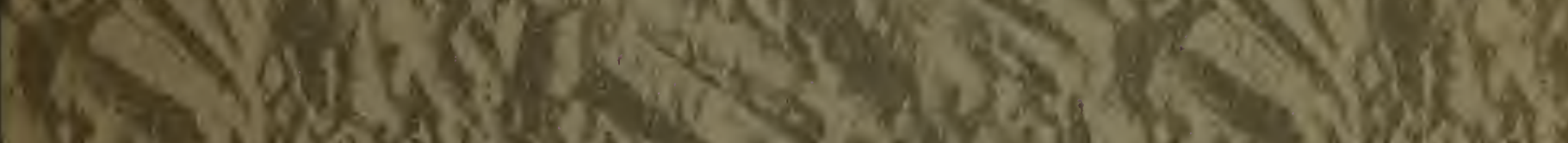
Ech

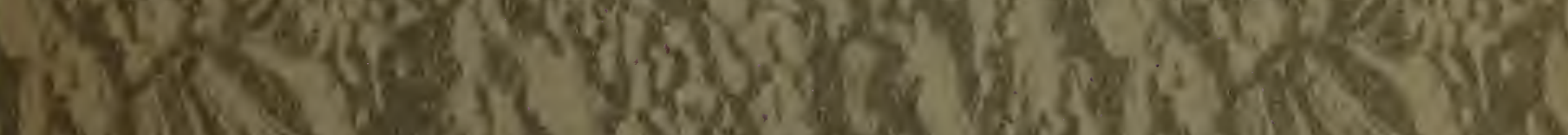
A.

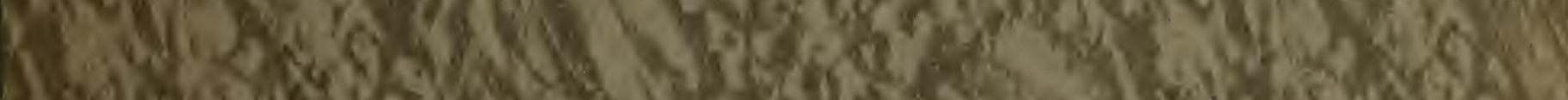

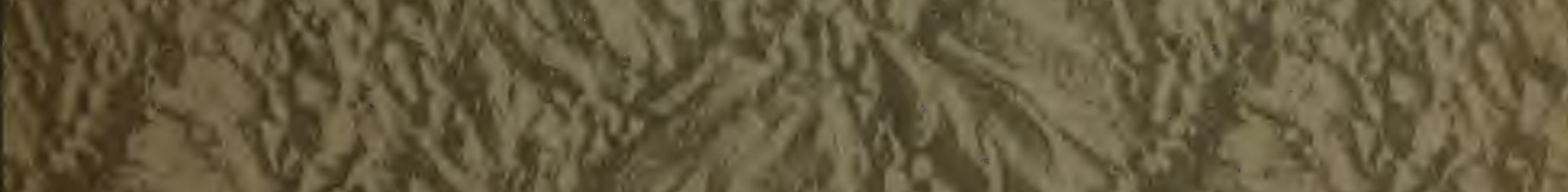

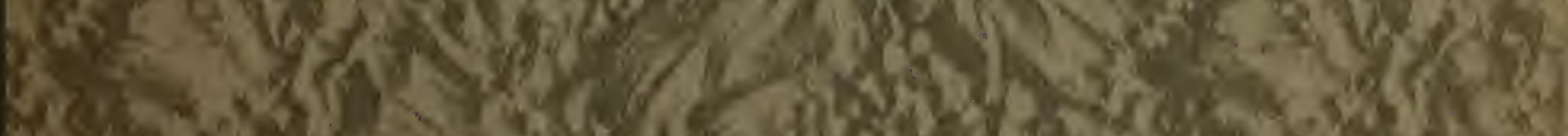

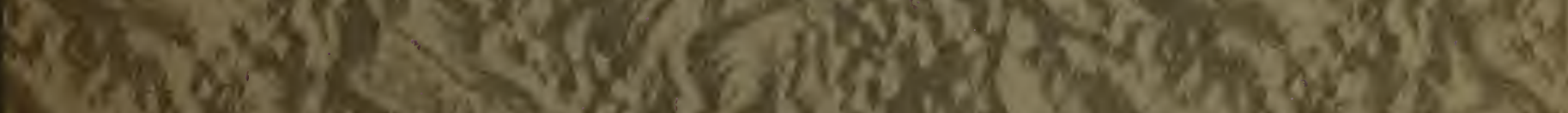

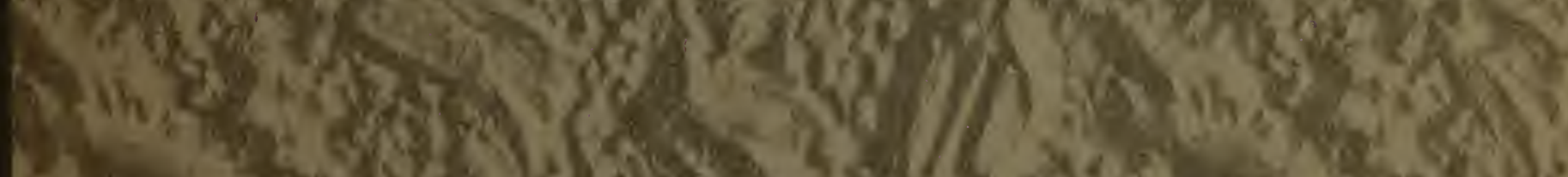
(2)

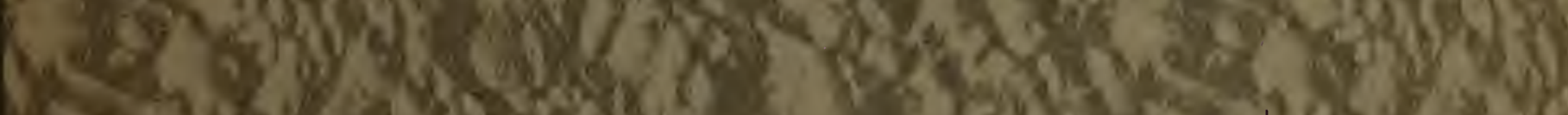

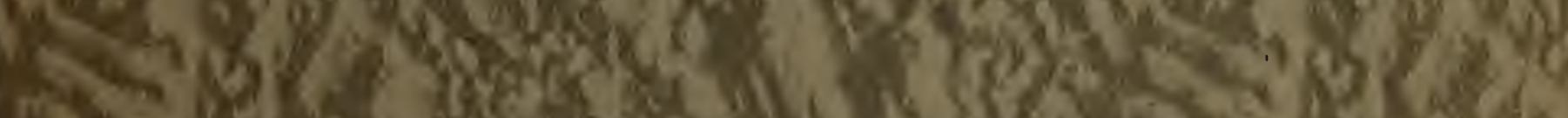

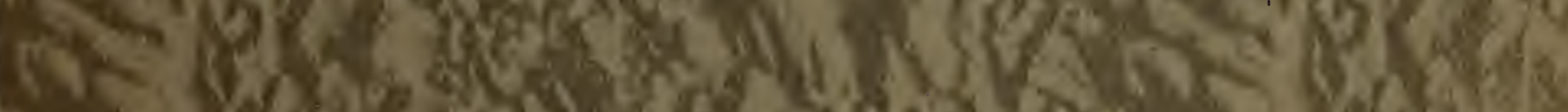

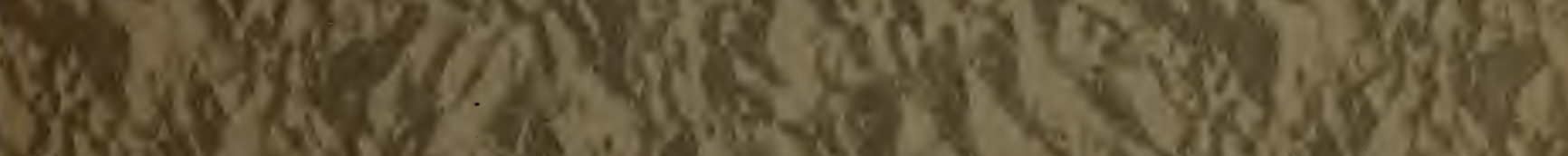

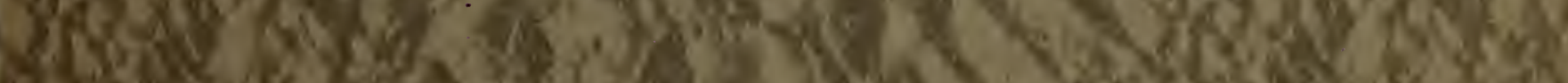

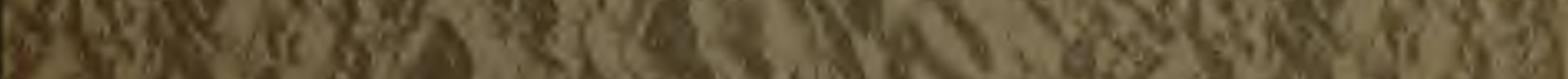

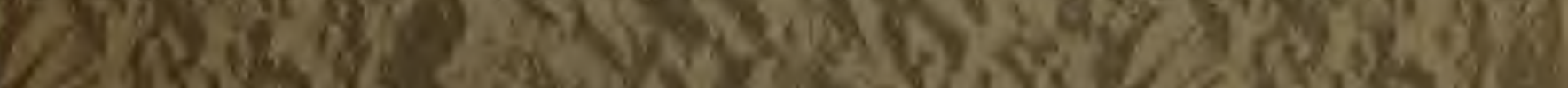

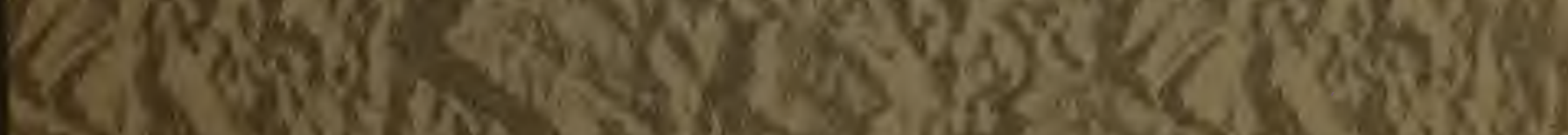

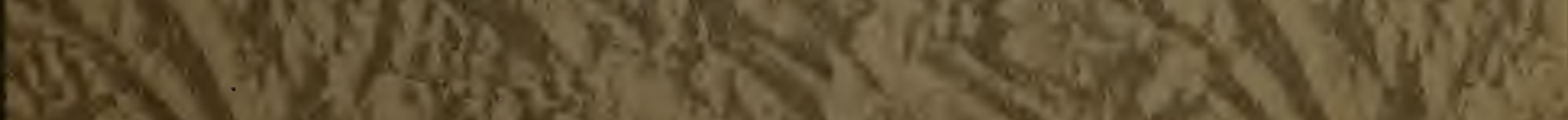





$$
\begin{aligned}
& \text { Syracuso, } N . Y . \\
& \text { Stockton, Calif. }
\end{aligned}
$$







\section{American Portraits}

\section{and Views}

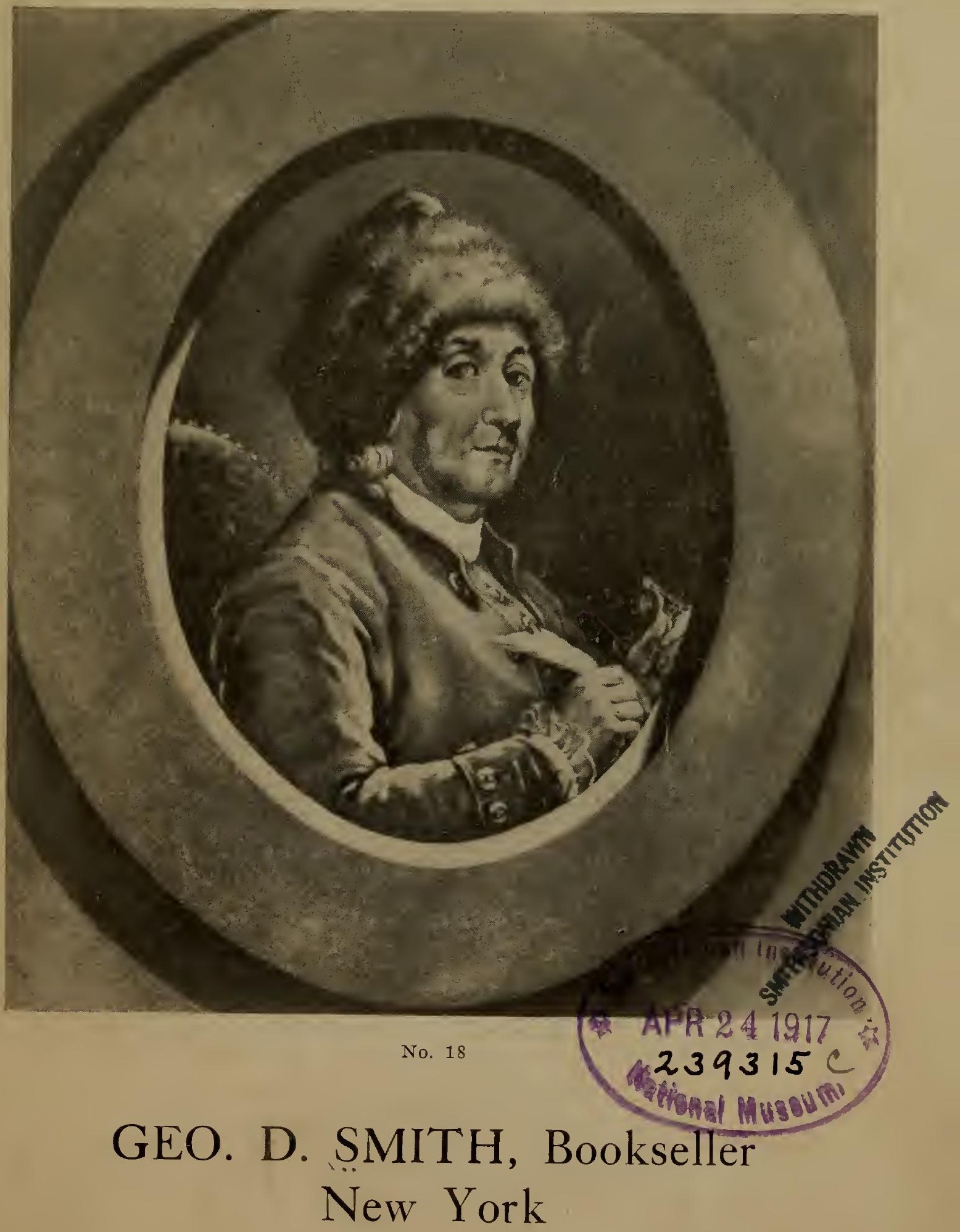




\section{JUST ISSUED}

Lincolniana. A Catalogue of Books, Pamphlets, Broadsides, Medals, Busts, Badges, Relics, Autograph Letters and Documents, Original Life Portraits and Engravings relating to Abraham Lincoln.

The Largest and Finest Lincoln Collection ever offered for sale by any American Bookseller, containing over Twelve hundred Titles and comprising very many Items of Supreme Importance and Value.

Copies will be mailed to Collectors and Public Libraries, on application.

\section{GEORGE D. SMITH, 547 Fifth Ave., New York.}

Telephone, Murray Hill 2626. 


\title{
bocksellers
}

\section{CATALOGUE}

of

American Historical Portraits and Engravings

\author{
Including
}

Rare Revolutionary Prints and Unique New York Views

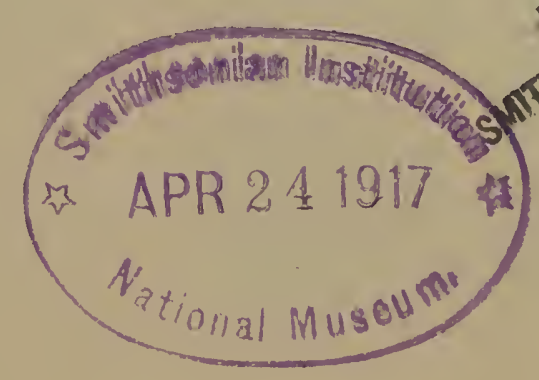




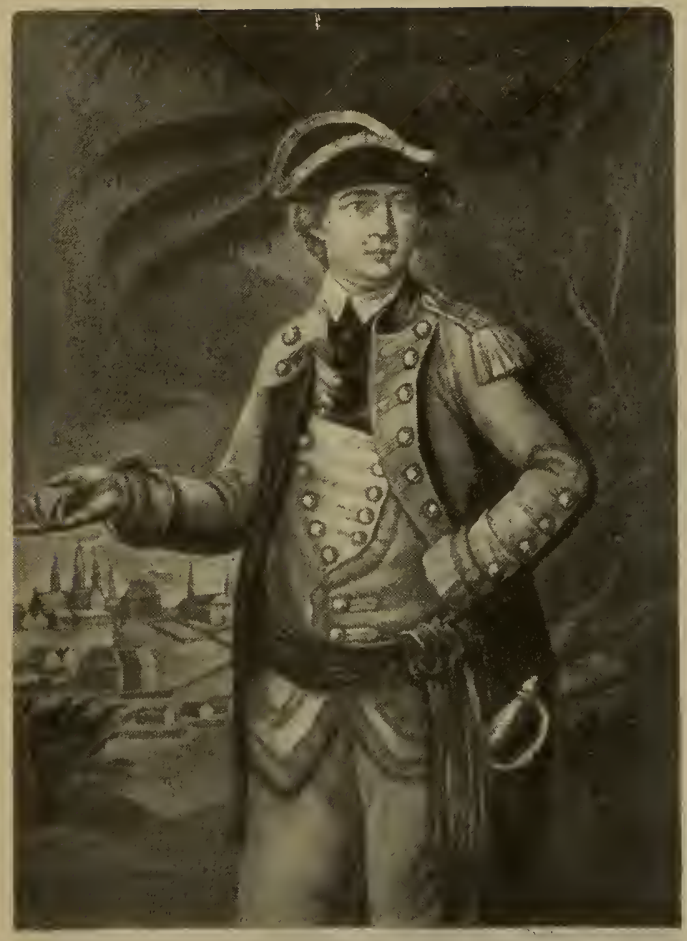

(OO.ONP. ArYOI,

No. 3

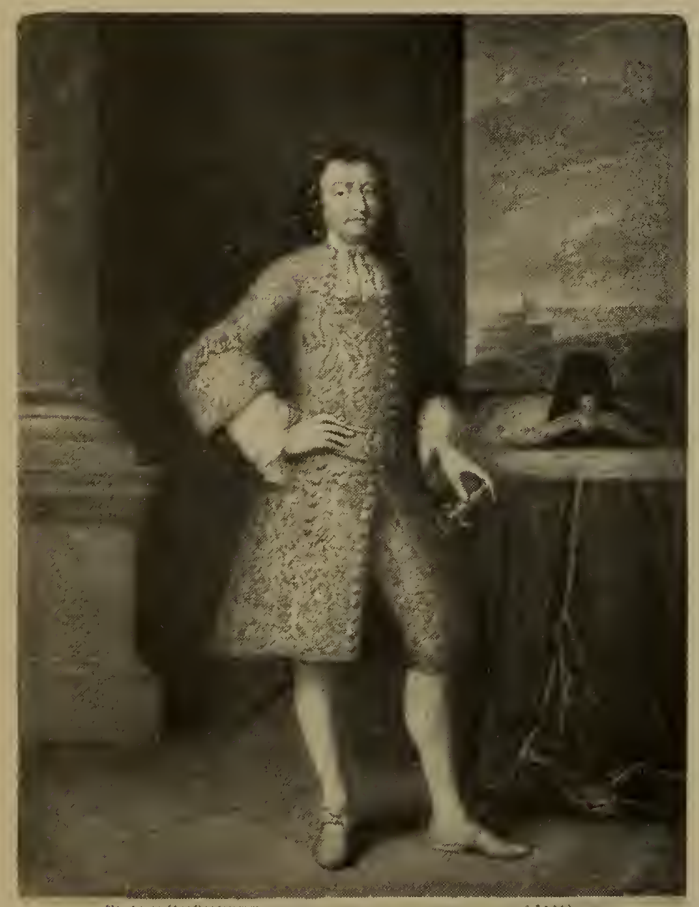

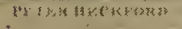

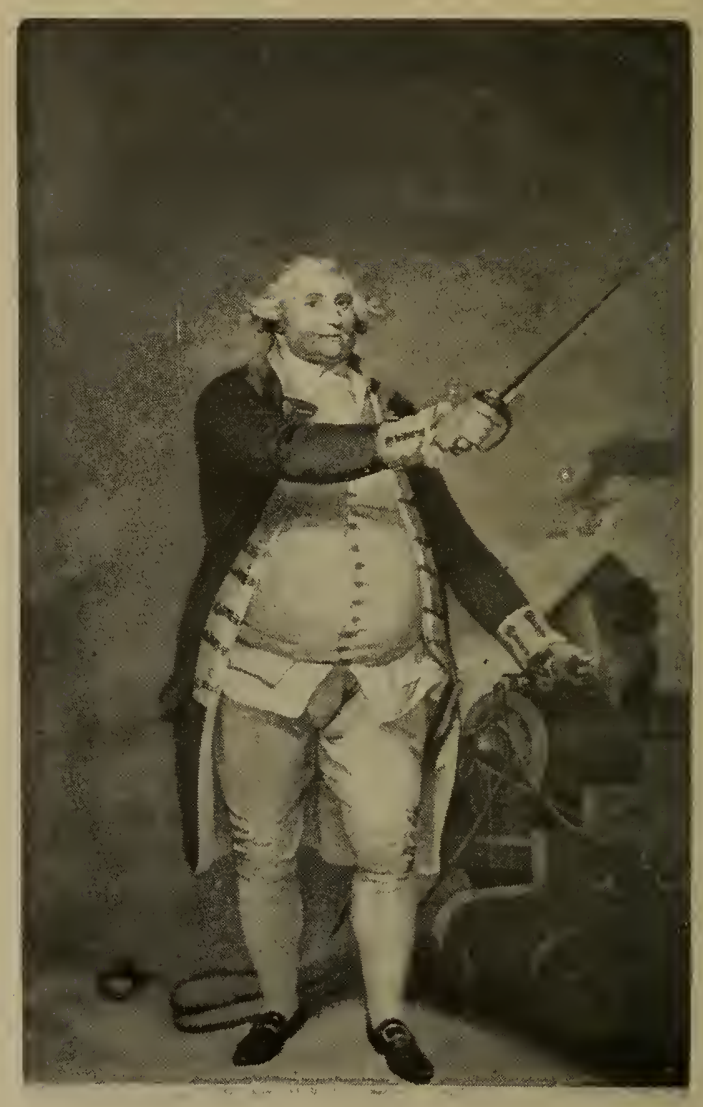

No. 16

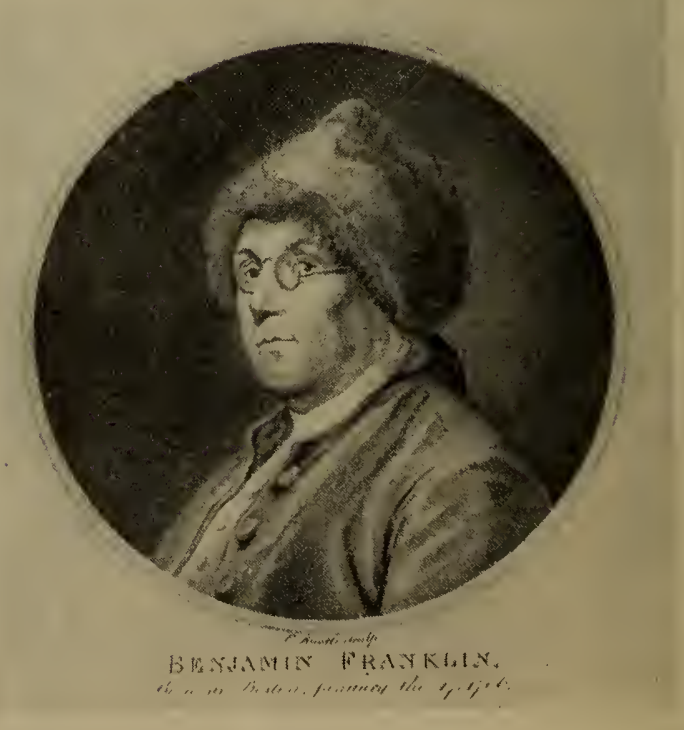

No. 20

No. 4 


\section{Catalogue}

1 ADAMS, JOHN QUINCY.

"John Quincy Adams." Half length seated. Book in hand. Line engraving by J. Andrews after G. P. Healy. Folio. Boston, 1848.

$\$ 7.50$

Fine and scarce.

\section{ARNOLD, BENEDICT.}

"Colonel Arnold, who commanded the Provincial troops sent against Quebec through the wilderness of Canada, and was wounded in storming that city under General Montgomery." Three-quarter length in uniform, with cocked hat. View of Quebec in background. John Martin Will excudit Aug. Vind. Folio. London. Thos. Hart, 1776.

$\$ 125.00$

Of the very greatest rarity and a beautiful impression.

\section{ARNOLD, BENEDICT.}

"Colonel Arnold, who commanded the Provincial troops sent against Quebec through the wilderness of Canada, and was wounded in storming that city under General Montgomery." Three-quarter length in uniform. Engraved in mezzotint, by Lorenz Rugendas. Folio. Augsburg. About 1776.

$\$ 165.00$

The rarest of all contemporary portraits of Arnold. Brilliant impression.

\section{BECKFORD, PETER.}

"Peter Beckford, Esq.; Lieut. Governor and Commander-in-Chief of Jamaica. He passed thro most of the military as zuell as civil employments of the Island, was for several years President of the Council, distinguished himself at the French Invasion, 1693. Fortified Port Royal and Commanded the Corps of Volunteers in the expedition against Hispaniola. Having been successful in all his Enterprises, he left a great Estate and vast Tracts of Land, which were much improied by his eldest son. Peter Beckford, Esq., who at his death was in possession of the largest Property, Real and Personal, of any Subject in Europe." Full length in court dress, most beautifully 
embroidered. View of Port Royal in background. Mezzotint engraved by John Murphy from the original painting at Fonthill. Folio. London. Edward Foxhall, 1793.

A very beautiful Old English mezzotint, not only interesting for its association with the West Indies, but also as depicting the father of William Beckford, the patron of John Wilkes and Thomas Chatterton, and grandfather of the author of "VATHEK," owner of the princely Fonthill library. VERY RARE.

\section{BURGOYNE, JOHN.}

"John Burgoyne." General in the British army. Witnessed the Battle of Bunker Hill. In command of the army which forced the evacuation of Crown Point, Ticonderoga and Fort Anne. Surrendered with his entire army to General Gates at Saratoga, October 17, 1777, the turning point of the American Revolution. Died in London in 1792.

$\$ 75.00$

The Original Sepia-Drawing of Gen. Burgoyne, in Uniform, with Cocked Hat, Very Finely Executed by J. Chapman, the Famous English Portrait Painter and Engrater. From this drawing he engraved in stipple the well-known portrait of Gen. Burgoyne, published in 1801 . The drawing is accompanied by a brilliant impression of the engraving. The portrait is oval in form, being $4 \mathrm{r} / 2$ inches high, the same size as the engraving, and is mounted on black glass, gilt, and framed in ebony.

6 CALHOUN, JOHN.

"John Calloun." Full length, standing, hand resting on documents on table inscribed "Sovereignty of the States," "Free Trade," etc. Engraved in line by A. H. Ritchie, after T. Hicks. Folio. New York. R. A. Bachia.

\section{CALIFORNIA.}

"Harbour and City of Monterey', California, 1842." Outline plan, with $3 \dot{3}$ references forming a directory of the inhabitants. Oblong folio. Monterey, 1842. $\$ 75.00$

Virtually the first Directory of Monterey in English. In the bay are seen the U. S. ships, "Cvane," "United States" and "Yorktorm," with the schooner, "California." Among the property owners are mentioned The Padres House, Thomas O. Larkin. George Kinlock, Carmen Pinto, David Spence, Wreck Commissioner Rodgers, Charles Wolter, Antonio Osio, Simeon Castro, James Stokes, and others.

\section{CALIFORNIA.}

"San Francisco, 1855." The magnificent panoramic etching executed by CHARLes Merion for T. R. Bayerque and $\mathrm{A}$. Pioche, the two bankers who gave him the commis- 
sion for the plate. Their portraits occupy two small medallions in the inscription tablet. The entire view is 38 inches long and $7 \mathrm{~T} / 4$ inches high. Paris. A. Delattre, 1856.

$\$ 75.00$

A proof presentation copy, with untrimmed margins. Meryon is described by Hamerton as one of the greatest and most original artists who have appeared in Europe. "He is one of the Immortals, and his name will be inscribed on the Noble roll, where Durer and Rembrandt live forever."

9 CANADA.

"Montreal from the Mountain," with title repeated in French. Engraved by J. Walker. Oblong folio. Montreal n. d.

$\$ 30.00$

Scarce.

\section{CHOATE, JOSEPH HODGES.}

Eminent Jurist. President of the Union League Club and of the New England Society in New York. Full bust. Full face. Proof impression on Japan paper signed by the artist, James S. King. Folio. New York, 1899.

$\$ 15.00$

Special copy, autographed by Mr. Choate.

\section{CLAY, HENRY.}

"Henry Clay." Full length, seated on a bank by a river. Dog in foreground. In border a vignette of Ashland. Engraved in mezzotint by H. Sadd, after J. Dodge. Folio. New York, 1843.

$\$ 6.00$

\section{CLAY, HENRY.}

"Henry Clay." Full length, standing. Head slightly to right. Table with books and cane to right. In stipple and line. Folio. New York. R. A. Bachia. About 1840.

$\$ 6.00$

\section{CLAY AND FRELINGHUYSEN.}

"Candidates for President and Vice President." Medallion portraits in ornamental and emblematic framework. American eagle and flags at head. Finely printed in colors. Folio. Hartford. Kellogg and Hammer, 1844.

Theodore Frelinghuysen was Chancellor of the University of New York, and in 1844 was nominated by the Whig Convention to run with Henry Clay in the Presidential Election of that year. Fine and scarce. 


\section{COLORADO.}

"The Rocky Mountains." Encampment of Indians in the foreground comprising numerous figures. In the background snow covered mountains, with waterfall and lake. Engraved by J. Smillie, after A. Bierstadt. Large oblong folio in fine gilt frame. New York, 1864. \$100.00 A Beautifully Colored Impression of One of Bierstadt's Finest Western Paintings. As a landscape engraver, Smillie has never been surpassed in America.

\section{DECLARATION OF INDEPENDENCE.}

Trumbull's fine picture of the Signing of the Declaration printed in purple upon linen, with key of the signers' heads below accompanied by the fac-simile autograph of each signer. Size, 30 inches wide by 28 inches high. No place or date, but about 1830 .

Of Connecticut Origin and Extremely Rare.

\section{DOUGLAS, SIR CHARLES}

"Rear Admiral Sir Chas. Douglas Bart." Full length in uniform, with drawn sword, giving orders on shipboard, with left hand resting on a gun. Engraved in mezzotint by J. Jones, after H. Singleton. Folio. London. C. Lowndes, $1791 . \quad \$ 125.00$

At the beginning of the American War, Admiral Douglas was in command of the squadron operating in the Gulf of St. Lawrence. In 1776 he forced his way up the river and relieved the City of Quebec and defeated the French at Dominica. He invented a mode of firing guns on board ships by means of locks instead of matches. This device is shown on the gun by his side.

17 DU SIMITIERE'S PORTRAITS.

"Thirteen portraits of American Legislators, Patriots and Soldiers, who distinguished themselves in rendering their Country Independent. Drawn from life by Du Simitiere, Painter and Member of the Philosophical Society in Philadelphia, and engraved by MR. B. Reading." Small folio, original half red roan. London. W. Richardson, 1783.

. $\$ 300.00$

Complete Set of Open Letter Proofs and Exceedingly Rare. The series comprises George Washington, Baron De Steuben, Silas Deane, General Reed, Governor Morris, General Gates, John Jay, W. H. Drayton, Henry Laurens, 'Charles Thompson, S. Huntingdon, J. Dickenson, and General Arnold. Splendid COPY.

\section{FRANKLIN BENJAMIN.}

Full bust to right. Spectacles in left liand and quill pen in the right. Messotint by Isaac Jehner. Oval in rectangle. 4to. London. About 1780.

$\$ 500.00$

The Rarest Engraied Portrait of Franklin in Existence; Only One Other Copy Being Known. A most brilliant impression. 
19 FRANKLIN, BENJAMIN.

"D. Benjamin Franklin, et aita inter Americanos acta, et magnis electricitatis periculis clarus." Full bust, nearly full face to left, long hair. Oval in rectangle over tablet. In mezzotint by I. E. Haid. 4to. Augsburg, 1778.

$\$ 35.00$

Fine and rare portrait of the Benjamin Wilson type.

20 FRANKLIN, BENJAMIN.

"Benjamin Franklin, born at Boston, Jamuary the 17 th, 1706." Bust to left in circle, with spectacles and fur cap. Engraved in stipple and beautifully printed in CoLORS, by C. Ruotte. 4to. 1780 .

$\$ 150.00$

One of the very finest and rarest of the French portraits of: Franklin. Very choice impression.

\section{FRANKLIN, BENJAMIN.}

Original oil painting by Duplessis, the famous French portraitist, painted for Mr. Barnet, the Consul General for the United States at Paris during Franklin's residency there. In the portrait the artist has depicted Franklin full bust slightly to the right wearing long hair, without spectacles, plain black coat and white scarf piece. Size, 22 inches by 15 inches, in old gilt frame. About 1780 .

$\$ 1,800.00$

A most important and highly valuable historical portrait.

22 FRASER, GENERAL SIMON.

"The Burial of General Fraser." Military group in various British uniforms. Engraved in stipple and printed in colors by Nutter, after Graham. Oblong folio. London. John Jeffreys, 1794.

$\$ 200.00$

An extremely rare and beautiful historical engraving. Fraser was with Wolfe at Quebec, and in 1777 as Colonel drove the Americans out of Canada, being in command at the severe battle at Three Rivers. He was then selected by Burgoyne to command the right wing of his army. After the evacuation of Ticonderoga he pursued the American troops under St. Clair and with Riedesel gained a signal victory at Hubbardtown. At Bemis Heights he opened the battle of October 7th by an attack on 'Morgan's skirmishes in which action he was mortally wounded by Tim Murphy, one of 'Morgan's riflemen, under that officer's instructions. He died the following morning and was buried at sunset by his particular request on a hill overlooking the Hudson. As the funeral party moved up the hill the American batteries opened fire, but ceased as soon as the nature of the gathering was known. Generals Burgoyne and Riedesel with Chaplain Brudenell are figured in the group, and in the background can be seen the American batteries in action. A Superb IMPREsSION. 


\section{FULLER, MELVILLE W.}

Chief Justice of the U. S., 1888-1910. Proof etching on parchment, signed by the artist, James S. King, and autographed by Chief Justice Fuller. Folio. New York, 1900.

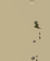
1910.

Melville W. Fuller, of Illinois, was born in 1833 and died in

24 GATES, HORATIO.

"Le General Gates qui a environné et fait prisonnier le General Lieutenant Bourgoyne, avec toute son Armée en Amerique." Peint par Thomlinson à Nouvelle Yorck. Half length in uniform. Oval in rectangle. Mezzotint. 4to. Londres, chez Thom. Hart. 1778.

$\$ 85.00$

A wonderfully fine impression of this excessively rare print.

\section{GATES, HORATIO.}

"Horatio Gates, Esq., Major General of the American Forces." Three-quarter length in uniform, head slightly. to left. The right hand is resting upon a table upon which are some documents inscribed, "Articles of Convention between Gen. Gates and Gen. Burgoyne." In the background tents and cannon. Folio. London. John Morris, 1778.

$\$ 75.00$

An American historical engraving of great rarity and value.

\section{GRANT, GENERAL.}

"Gen. Grant and His Family." Engraved in mezzotint by John Sartain after the painting by William Cogswell. Folio. Washington, 1868.

$\$ 10.00$

\section{GRANT, GENERAL.}

"U. S. Grant." Full bust. Oval in rectangle. Finely engraved in line by H. B. Hall's Sons. Folio. New York, 1885.

28 HANCOCK, JOHN.

"The Honble. John Hancock of Boston in Neru England; President of the American Congress. Done from an Original Picture painted by Littleford." Mezzotint oval in rectangle. Vividly colored. Folio. London. C. Shepherd, 1775 . $\$ 125.00$

A very uncommon Hancock portrait, depicting the Governor of Massachusetts in a bright green coat laced with gold, frills and a white wig. 


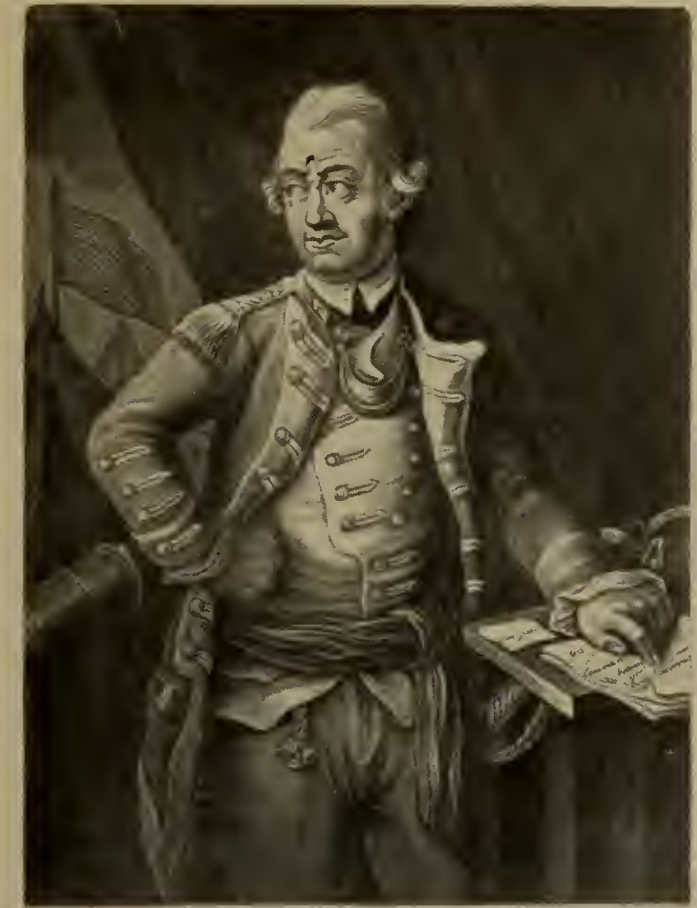

HOR ITIO C ViT:S F S.

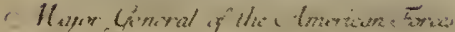

No. 25

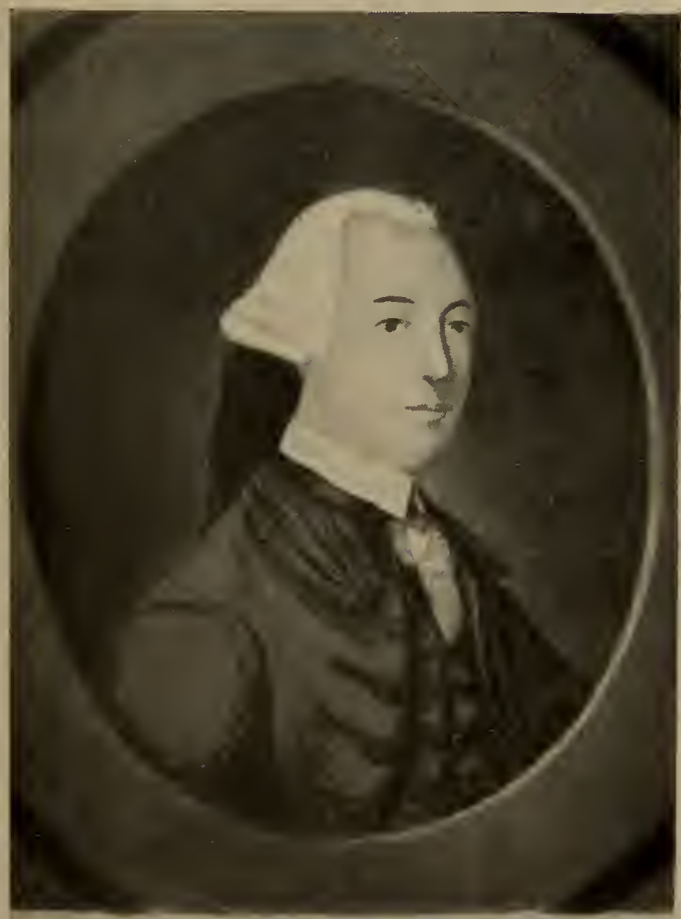

The Hot JoHx Haxcor:k.

No. 28

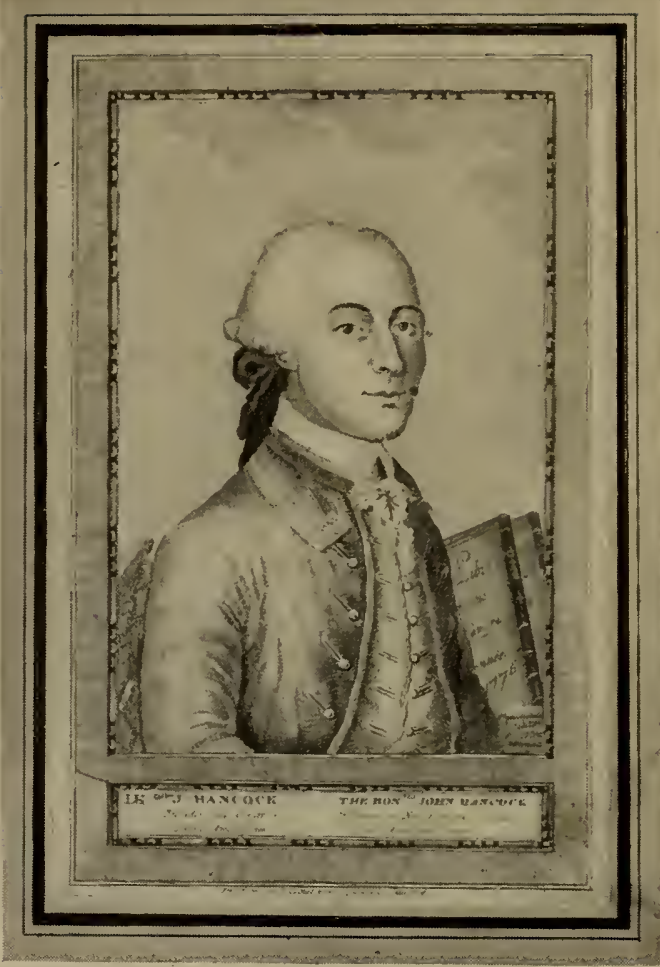

No. 31

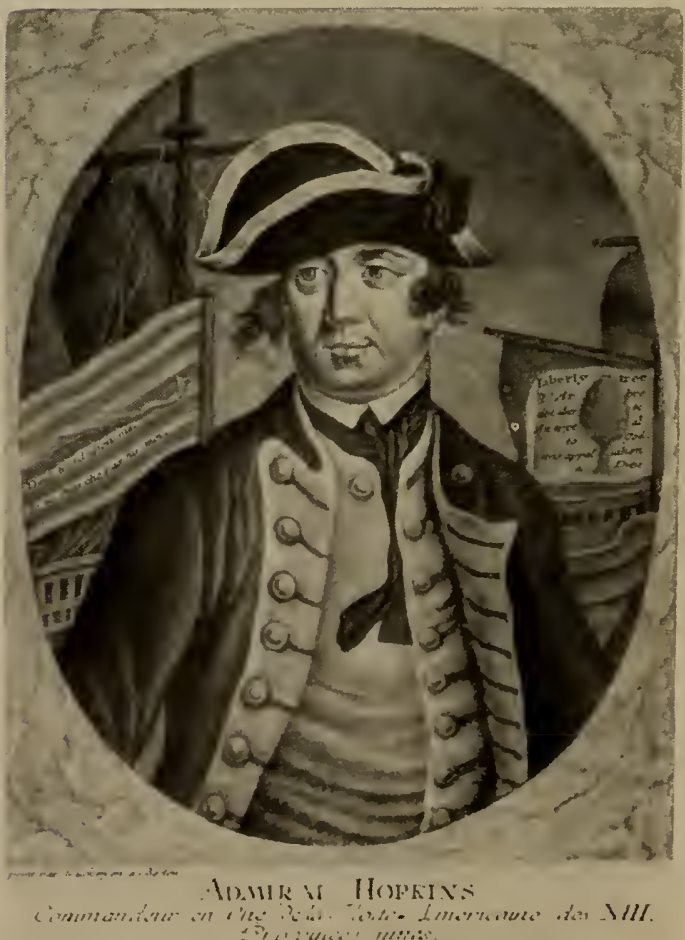

No. 35 


\section{HANCOCK, JOHN.}

"The Honble. John Hancock of Boston in New England; President of the American Congress. Done from an Original Picture painted by Littleford." Three-quarter length, standing to left. In his right hand a letter addressed, "Mons. Israel Putnam, Major General a Long Island." Mezzotint. John Martin Will excudit Aug. Vind. Folio. London. C. Shepherd, 25th Oct., 1775.

Extremely fine. Only three copies known.

$\$ 225.00$

30 HANCOCK, JOHN.

"John Hancock, Esq., President of the American Congress. From an Original Picture painted at Boston." Half length, oval in rectangle. Mezzotint. Small 4to. London, 1776.

$\$ 35.00$

Rare. Choice impression.

\section{HANCOCK, JOHN.}

"Le Celebre J. Hancock, President du Congres EngloAmeriquain." With English title, "The Honble. John Hancock of Boston in New England, President of the American Congrese." Line engraving done from an original picture painted by Littleford. Full bust to right in line frame. At his back two large books inscribed, "Resolutions of Congress, 1776," and on the left-hand side a rolled map inscribed, "Delaware Bay." Folio. Paris, 1776.

Of this rare and fine portrait there was no copy in the Carson collection, claimed to be the largest Hancock collection known.

\section{HANCOCK, JOHN.}

"Jean Hancock, President au Congrès des XIII Provinces Unies d'Amerique, né à Boston." Peint par Jean Wilckinson a Boston. Full bust to right. In military uniform, with wig and queue. Mezzotint oval in rectangle. Small folio. Londres chez. Thom Hart. About 1776.

$\$ 90.00$ sion.

One of the rarest Hancock portraits known. Beautiful impres-

\section{HARRISON, WILLIAM HENRY.}

"General William H. Harrison." Half length in uniform. Head slightly to riglit. Powerful lithograph by Sarony. Folio. New York, n. d. 


\section{HAWTHORNE, NATHANIEL.}

Author of "The Scarlet Letter." Full bust to right. Remarque proof etching on Japan paper by Henri Lefort, signed by the artist. Folio. New York, 1897. \$15.00

The rare Grolier Club limited issue.

\section{HOPKINS, ADMIRAL.}

"Admiral Hopkins, Commandeur en Chef de la Flotte Americaine des XIII Proinces Unies." Half length in uniform, with flags in rear, inscribed, "Don't Tread Upon Me," and "Liberty Tree," both in English and French. Oval in rectangle. Painted by Wilckenson of Bostox. Small folio. London. Thomas Hart. 1776. $\$ 125.00$

Esek Hopkins, of Rhode Island, was the First Commander in Chief of the American Army, receiving his Commission from the Continental Congress in December, 1775. He was officially addressed by Washington as Admiral Hopkins, and in February, 1776 , he put to sea with the first squadron sent out by the Colonies. It consisted of four ships and three sloops and did much execution in the Bahamas. Charges were brought against him for not engaging the "Glasgow" of 29 guns off Block Island and after various proceedings he was dismissed from the service. A Most Important Rhode Island Historical Item.

\section{HOWE, RICHARD LORD.}

"The Right Honble. Richard Lord Howe, Commander" in Chief of his Majesty's Fleets in America." Threequarter length in naval uniform, drawn sword in right hand, and with the left pointing to ships in the background. Mezzotint by and after Corbutt, otherwise R. Purcell. Folio. London. John Morris, 10th Nov. 1778.

$\$ 200.00$.

Magnificent impression and exceedingly rare. Lord Howe had just acquired great renown in England by forcing the passage of the Delaware. In 1782 he effected the Relief of Gibraltar.

\section{HOWE, RICHARD LORD.}

"The Right Honble. Richard Lord Howe, Commander in Chief of his Majesty's Fleet in the Channel." Threequarter length in naval uniform, drawn sword in right hand, the left pointing" to a ship named "Qucen Charlotte." Mezzotint by Corbutt. Folio. London. Laurie and Whittle, 1794.

$\$ 150.00$

A rare and fine print issued just after Admiral Howe's great victory over the French fleet in the Channel. 


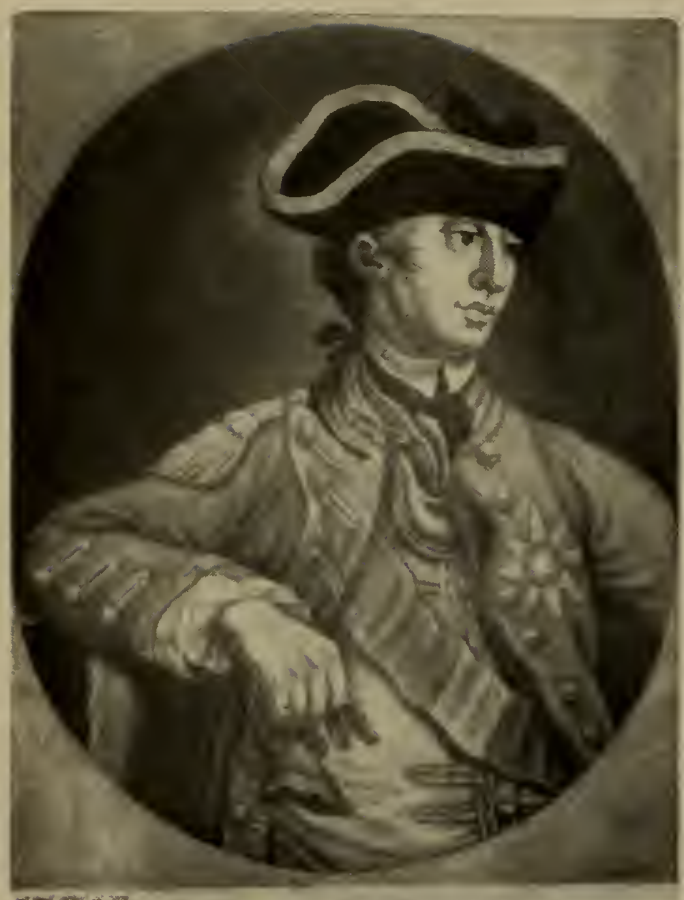

Dhe HON $5:$ W. HOWE.

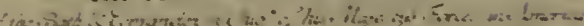

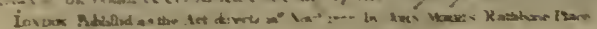

กัo. 3ร

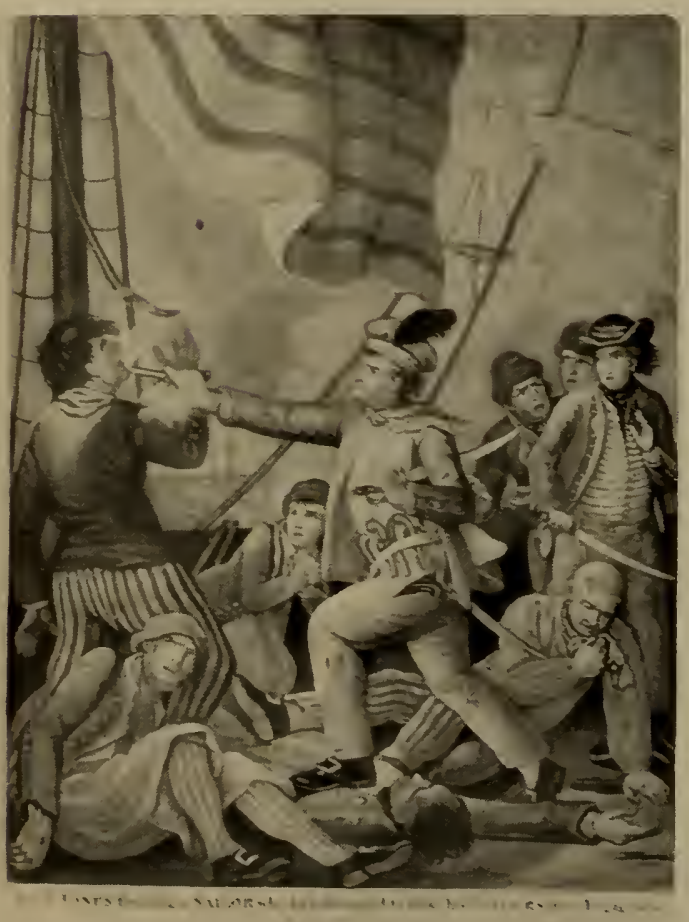

No. 42

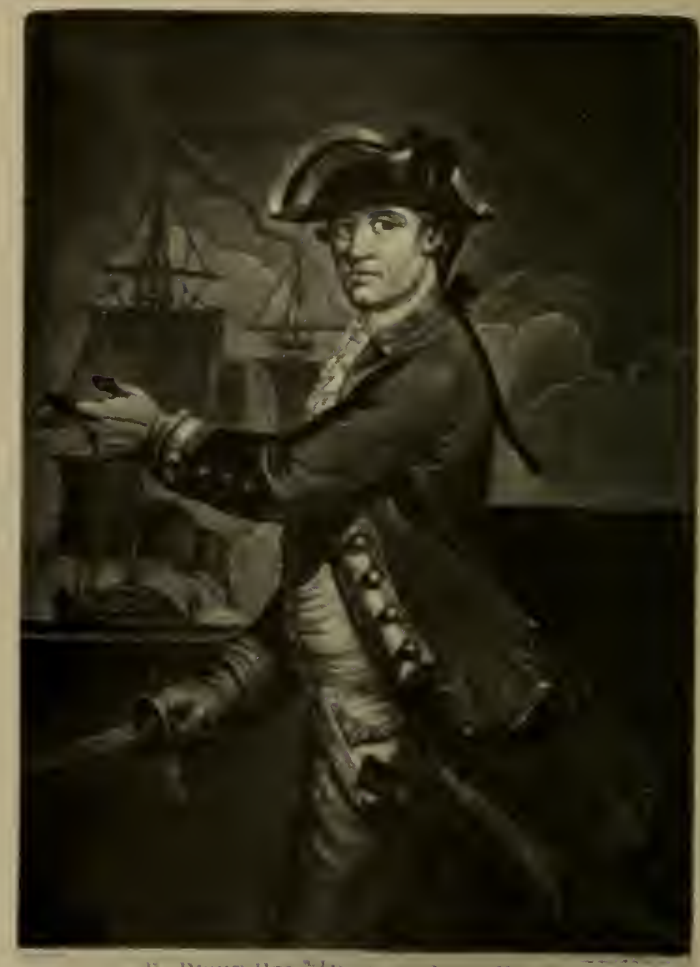

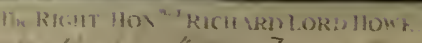

พัo. 35

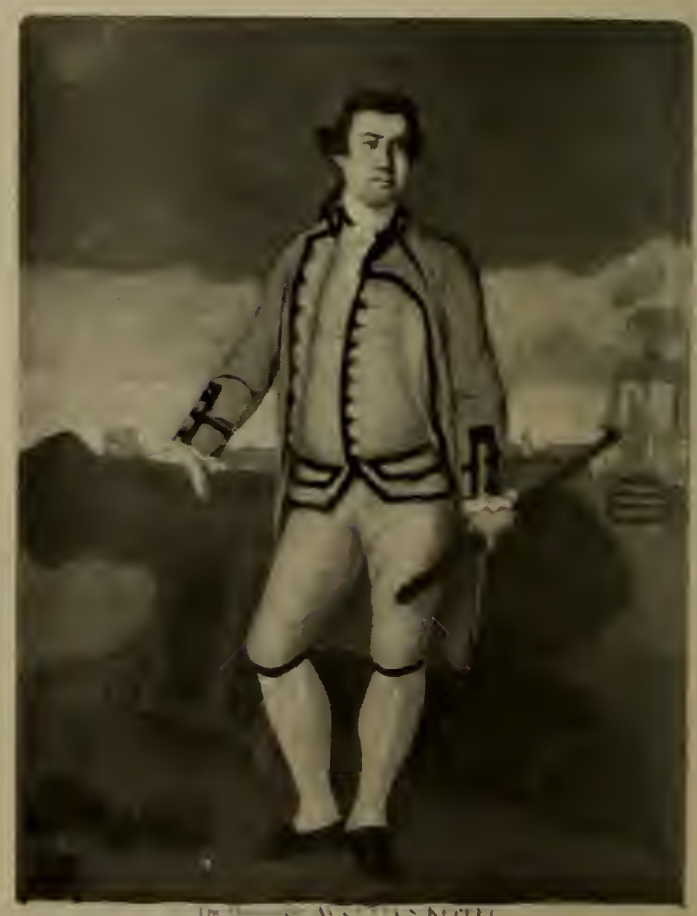

No. 43 


\section{HOWE, SIR WILLIAM.}

"The Honble. Sr. Wm. How'e, Knight of the Bath and Commander in Chief of his Majesty's Forces in America." Half length, in uniform, with ribbon and star. Oval in rectangle. PRINTED IN RED. Drawn and engraved in mezzotint by Corbutt. Small folio. London. John Morris, 1777.

$\$ 100.00$

A very rare mezzotint portrait, unknown to J. C. Smith, of one of the most successful English soldiers of his time. He was educated at Eton, commanded a regiment at the capture of Louisbourg and led the Forlorn Hope at the Heights of Abraham. Succeeded Gage as commander in the American Colonies. Evacuated Boston and in 1776 defeated the American forces on Long Island. Captured New York and won battles of White Plains and Brandywine. In 1777 failed to draw Washington into further action after taking Philadelphia and resigned his command in 1778.

\section{IRVING, WASHINGTON.}

Original pencil drawing of Washington Irving, Daniel Webster, and William Cullen Bryant, by Daniel HuntINGTON, on the occasion of the memorial meeting of the New York Historical Society in celebration of James Fenimore Cooper, whose death had occurred in September of 1851. Signed by the artist, "D. Huntington, del Cooper Festival, 24 Feb., 1852." Size, 15 inches by 12 inches, in old gilt frame, 1852.

$\$ 250.00$

Of extreme Washington Irving interest as it was through the influence of Webster that he had received his appointment as Minister to the Court of Spain.

40 JACKSON, ANDREW.

"Jackson." Bust nearly full face. Line and stipple engraved by T. B. Welch, after the original, by THomas Sully. Folio. Philadelphia. Geo. IV. Childs, n. d.

Proof impression. Scarce.

41 JEFFERSON, THOMAS.

"Thomas Jefferson, President of the United States." Full length, standing, face three-quarters right, right hand holding Declaration of Independence on table to left, beneath a bust of Franklin. Electrical machine and globe to right. Engrazed in stipple by Tiebout, after Peale. Folio. Philadelphia, about 1801.

An exceedingly rare life engraving of Jefferson. 
42 JONES, JOHN PAUL.

"Paul Jones shooting a Sailor who had attempted to strike his colours in an engagement." Full length in uniform, with a Scotch cap, on board a man-of-war, with numerous wounded sailors on deck. Mezzotint, after John Collet. Folio. London. Carington Bowles, 1779.

$\$ 150.00$

A highly dramatic and very rare representation of the "Father of the American Navy."

42a JONES, JOHN PAUL.

"Paul Jones. Intrépide Marin Ecossais au sericice des Americains né en 1727, mort à Paris 1792." Engraved by Varin. Full bust, head to right. Cocked hat. Printed in brown. 4to, Paris. Vignères, 1875.

$\$ 7.00$

An uncommon and very characteristic head.

42b JONES, JOHN PAUL.

"Paul Jones the Pirate." A highly dramatic and very curious picture of Jones in pirate's dress with an immense cocked hat adorned with the death's head and cross bones. Pistol in left hand and huge sabre in right. In the background a ship exploding and sailors fighting. Apparently the only portrait of Jones wearing fierce black whiskers. 4to. Tabernacle Road. A Park. About 1820. $\$ 17.50$

Rare.

\section{KEPPEL, AUGUSTUS.}

"The Honorable Augustus Keppel, Admiral of the Blue Squadron, and Commander in Chief of His Majesty's Fiect rothich engaged and defeated the French on the 27 th and 28th of July, 1778, off Ushant." Full length, leaning against a gun. In the background several ships, one named "Victory." Brilliantly colored mezzotint. Folio. London. Carington Bowles, 1779.

$\$ 75.00$

A scarce portrait of this English sailor. He accompanied Anson on his voyage around the world and saw much service in the Mediterranean against the Algerine and Tripoli pirates.

44 LAFAYETTE, MARQUIS DE.

"M le Marquis de Lafayette-M. Bailly." Full bust, profile to right. In uniform. Mezzotint printed in colors. Portrait of Bailly facing. Circular medallions in rectangles. Oblong, 4to. Paris, chez Crèpy, 1793. $\$ 50.00$

Rare and extremely fine. 


\section{LAFAYETTE, MARQUIS DE.}

"Republique Francaise 1793." Group containing miniature heads of Lafayette, Mirabeau, Bailly, Marat and Robespierre. Circle in rectangle. Size, 31/4 inches square. Paris, 1793.

Rare colored design for a Revolutionary snuff box.

\section{LAFAYETTE, MARQUIS DE.}

"La Fayette traité comme il le merite par les Democrates et les Aristocrates." Caricature in aquatint of the hanging of Lafayette to a lamp-post, inscribed underneath: "Tu seras pendu fameux. General n'en demande pas davantage." Oblong. 12mo. Paris, 1795.

$\$ 15.00$

A very scarce French Revolutionary caricature.

\section{LEE, CHARLES.}

"Charles Lee, Esq., Major General of the Continental Army in America." Thomlinson pinxit. Three-quarter length in uniform and cocked hat. Right hand extended pointing to a flag inscribed, "An Appeal to Heaven." In the background a battery of cannon in action. Mezzotint. Folio. London. C. Sheperd, 31st October, 1775. \$200.00

Splendid impression and exceedingly rare.

\section{LINCOLN, ABRAHAM.}

"Lincoln and His Family." Engraved in mezzotint by William Sartain, after the painting by Waugh. Oblong folio. Philadelphia, 1866.

$\$ 10.00$

Choice impression.

\section{LINCOLN, ABRAHAM.}

Profile bust to right. Proof etching by T. Johnson. Folio.

\section{LINCOLN, ABRAHAM.}

"Abraham Lincoln, President of the United States." Full length, seated at desk, on which is a bust of Andrew Jackson, with books and lamp. Facing front. Engraved in mezzotint by John Sartain, after a photograph. Folio. Chicago, 1860.

Proof impression of a very uncommon Lincoln engraving.

\section{NIAGARA.}

"Niagara Falls, American Side." Engraved at J. M. Butler's, after a painting by J. Hamilton. Mezzotint in old walnut and gilt frame. Oblong folio Philadelphia. Wm. Smith, n. d. 
52 NIAGARA.

"Niagara Suspension Bridge, connecting the Great Western Railway of Canada with the New York Central Railway. Opened for Traffic Mar. 19, 1855. Engineer, Joln A. Roebling." Very fine colored lithograph, with details and statistics of construction in lower margins. Oblong folio. London. IVaterlow \& Co., 1855. \$20.00 Rare.

\section{NIAGARA.}

The Falls seen from below the American side. Original water color drawing by Appleton in the impressionist manner. Oblong folio.

$\$ 25.00$

\section{NIAGARA.}

The Falls. Lithographed in colors by C. Risdon, after F. E. Church. Long. Oblong folio. A pair. $\$ 25.00$

\section{NIAGARA.}

"The Falls of Niagara. View of the American Falls from Goat Island." Beautiful colored aquatint by C. Bently from a drawing by Col. Cockburn. Oblong folio. London. Ackermann, 1854.

\section{NIAGARA.}

Niagara Falls. Engraved by William Byrne, after Richard Wilson. Proof impression. Oblong folio. London, 1772 .

\section{NEW YORK.}

"View from Trinity Church looking down WALL StreET, with Sketches of the Buildings on each side and the Heights of Brooklyn." Lithographed by P. MAVERICK, after HUGH Reinagie. Oblong folio. New York, about 1825.

The Most Important and Most Interesting Viein of Wall Street in Existence. Only three copies of it are known.

\section{NEW YORK.}

"New York from Hobuck Ferry House, New Jersey." Engraved in aquatint by Francis Jukes, after the original painting by Alexander Robertson. Oblong folio in old gilt frame. London and New York, 1800. $\$ 750.00$

a Very Rare and Very Beautiful Vieiv Charmingly Colored. Alexander Robertson took lessons in England from the famous miniaturist Shelley and came to America in 1792 and was highly successful as a landscape painter in water colors. 


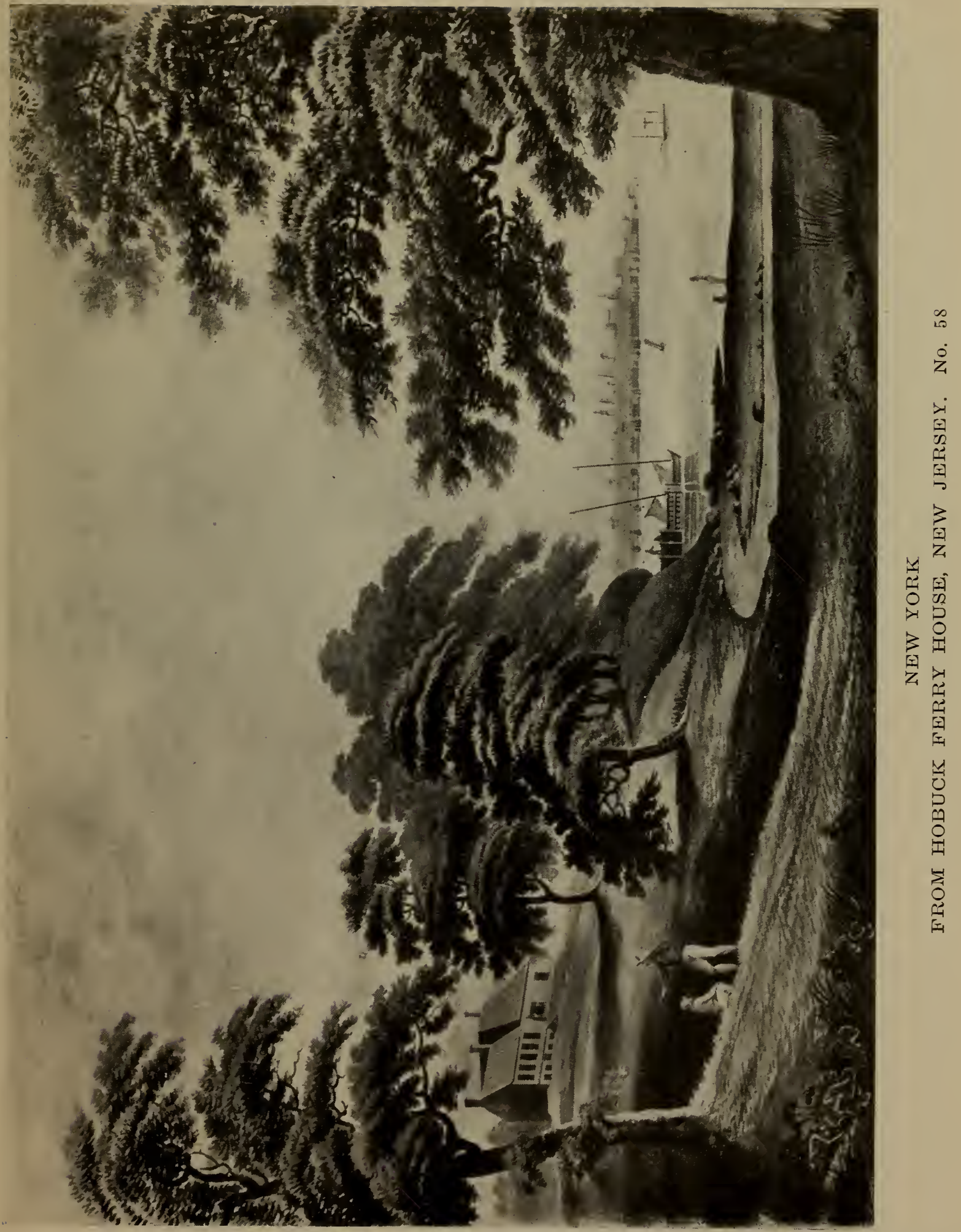




\section{NEW YORK.}

"The American Fireman. Always Ready." Old New York fireman with hand engine and drawing attachments. In colors. Drawn by F. Maurer. Folio. New York. Currier and Ives, 1858.

$\$ 15.00$

A very interesting relic of the Old New York Fire Department and now very scarce.

60 NEW YORK.

"To His Excellency Sir Henry Moore, Captain General and Chief, in and over the Province of Nerv York and the Territories depending thereon in America, Chancellor and Vice Admiral of the Same. This Plan of the City of NEW YORK is most humbly inscribed by His Excellency's most Obedient Servant, BERnd. Ratzen, Lieut. in the 60th Regiment. Surveyed in 1767." Engraved BY T. Kitchin. Large oblong folio. London, 1767. \$350.00

The rare issue with Ratzer's name incorrectly spelled Ratzen by the engraver. Other mistakes which were afterwards corrected are "Deekman's" Street for "Beekman." Cliff Street is here called "Clist." Whilst Bridge Street appears here as "Wyne Coop" and the "Ropewalk" extending along the line of Division Street disappeared altogether from the Ratzer map. Another street here known as "Judith" does not appear under that name in the Ratzer. There are many other variations of interest which will be found fully described in the "Iconography of Manhattan Island," by I. N. Phelps Stokes. He only mentions knowing three copies of the plan, and says in conclusion: "ThE RATZEN AND Ratzer Plans are the Most Accurate and Reliable Which we Have of New York at This Period, and are Even To-day Much Used in Searching Titles."

\section{NEW YORK.}

Series of twelve etchings of historic buildings of Old New York. Includes Bowling Green in Colonial TimesThe Old Beekman House-The Federal Hall in Wall Street-The Old Stone Bridge at Broadway and Canal Street-Hall of the Tammany Society at Park Place and Frankfort Street-Old City Hall in Wall Street-The Old Florence Road House-Martlings in 1778-St. Paul's Church and the Broadway Stage in 1831-Broadway between Fulton and Barclay Street-OId Van Rensselaer Manor House-John Jacob Astor's House at 85th Street and East River. The set of 13 proofs on Japan paper. 


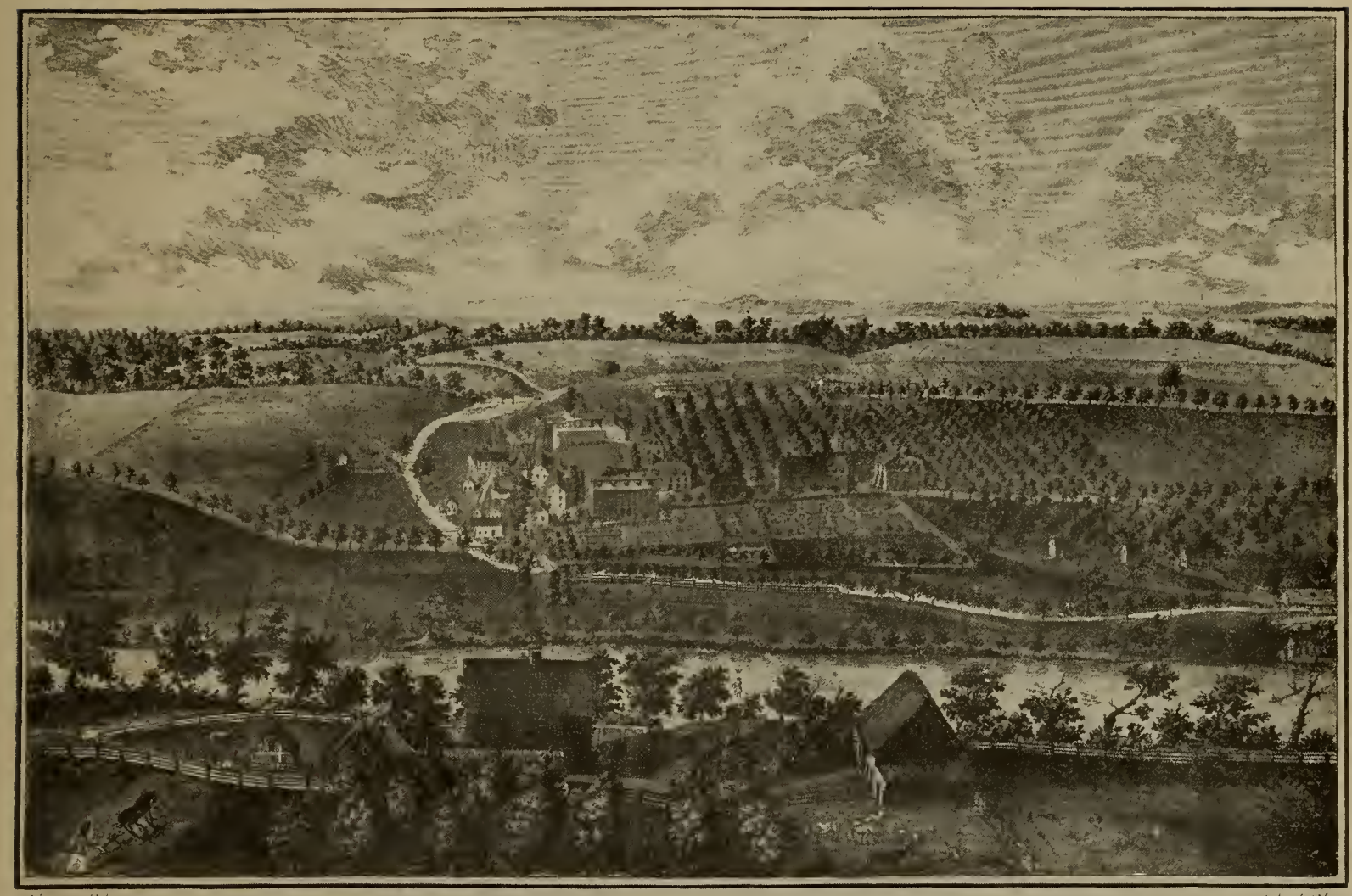

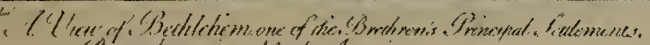

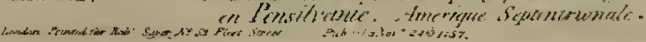

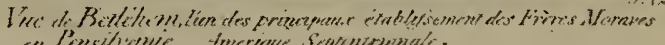

62 PENNSYLVANIA.

"A View of Bethlehem, one of the Brethren's Principal Settlements in Pennsylvania, North America." With French title also. Engraved in line by J. Noual, after N. Garrison. Finely colored by an old hand. Oblong folio. London. Robert Sayer, 1757. $\$ 200.00$

Very rare. In the lower margin of mat a very interesting directory, containing about 26 references, has been added in very neat manuscript.

\section{PENNSYLVANIA.}

"A View of Bethlem, the Great Moravian Settlement in the Province of Pennsylvania. Sketched on the Spot by his Excellency Governor Pownal. Painted and Engraved by Paul Sandby." With title also in French: "Vue de Bethlem Principal Etablissement des Freres Moraves." Line engraving. Oblong folio. London. For John Bowles and others. About 1755 . $\$ 175.00$

One of the earliest views of the famous Settlement which was founded in 1740 . 
64 PARKER, HYDE.

"Hyde Parker, Esq., Vice. Admiral of the Blue, Commander in Chief of his Majesty's Ships in the North Sea on the 5th of August, 1781." Engraved in mezzotint by I. R. Sm:th, after J. Northcote. Half length, in uniform, face to right. Oval in rectangle. Folio. London. I. R. Smith, 1781.

$\$ 125.00$

Sir Hyde Parker defeated the Dutch in 1781 in the North Sea, was captain of "Phoenix" in 1776 and took part in the attack on New York. He also participated in the capture of Savannah in 1778.

\section{PENN, THOMAS.}

"Thomas Penn, Esq. One of the First Proprietors of Pensilvania, 1751." Engraved in mezzotint by Martin, after Davis. Half length. Face to right. Wearing a richly embroidered costume and wig. Folio. London, 1751 .

$\$ 175.00$

Brilliant impression of this very rare portrait.

66 PENN, WILLIAM.

"William Penn's Treaty with the Indians, when he founded the province of Pennsylvania in North America, 1681." Engraved in line by John Hall, after Benjanin West. Oblong folio. London. John Boydell, 1775.

$\$ 40.00$

Fine strong impression of this famous historical engraving.

67 PRESIDENTS OF THE U. S.

"Washington, 1789, to Fillmore, 1850." Finely colored group containing 13 medallion portraits, with Washington in the centre, surrounded with the national emblems. Folio. New York. N. Currier, 1850.

$\$ 6.00$

Scare and fine.

68 RAILROADS.

Unique old railroad relic, being one of the ornamental panels cut from one of the cars destroyed in the memorable wreck on the Camden and Amboy Railroad at Burlington, New Jersey, August 29th, 1855. The painting, which is exceedingly well executed, represents an Italian lake scene, with marble terrace in foreground. It is especially of very considerable interest as displaying. the attention paid by the railroad heads to the interior decoration of their cars at this period. The cars were constructed at the railroad shops at Bordentown, and the 
panel was preserved as a memento of the disaster. The very solid frame is composed of moulding that was also taken from the car. Size, 20 inches by 17 inches. Bordentown, 1855.

$\$ 50.00$

\section{RAILWAY.}

"Pleasure Railway at Hoboken." Very curious lithographic view of a circular track on which two couples are propelling themselves in small chariot-shaped cars. Apparently situated in some public park or pleasure grounds, with numerous figures either seated or promenading. Size, 11 inches by 8 inches. Hartford. D. IV. Kellogg. About 1827.

$\$ 35.00$

An extremely curious and interesting New Jersey item.

70 REED, THOMAS BRACKETT.

Republican legislator from Maine. Speaker of the House, known as "The Czar." Full bust. Full face. Proof etching on parchment signed by the artist, James S. King. Folio. New York, 1899.

$\$ 20.00$

\section{ROGERS, ROBERT.}

"Major Robert Rogers, Commandeur en chef des Indiens dans les Habitations derrieres d'Amerique." Peint par Thomlinson a Nouvelle Yorck. Half length in uniform, with wampum belt. Oval in rectangle. Mezzotint. 4to. Londres, chez Thom. Hart, $1776 . \quad \$ 75.00$

Powerful impression. Very rare.

\section{ROGERS, ROBERT.}

"Major Robert Rogers, Commander in Chief of the Indians in the Back Settlements of America." Threequarter length in military costume, with 3 Indians, armed and plumed, in the background. Mezzotint. Folio. Augsburg. L. Rugendas, 1776 . $\$ 125.00$

A rare mezzotint engraving of the greatest interest to Indian collectors. Rogers was born at Dumbarton, New Hampshire. Commanded "Roger's Rangers" in the great war with the French and Indians from 1755 to 1760 . Compiled his famous "Journals" and "Concise Account of North America" which contain the most authentic details recorded of Indian warfare and border life of the period. In 1765 Rogers was appointed Governor of Mackinaw. He left a diary of the Siege of Detroit by Pontiac which was published in 1860 . All his portraits are rare. 


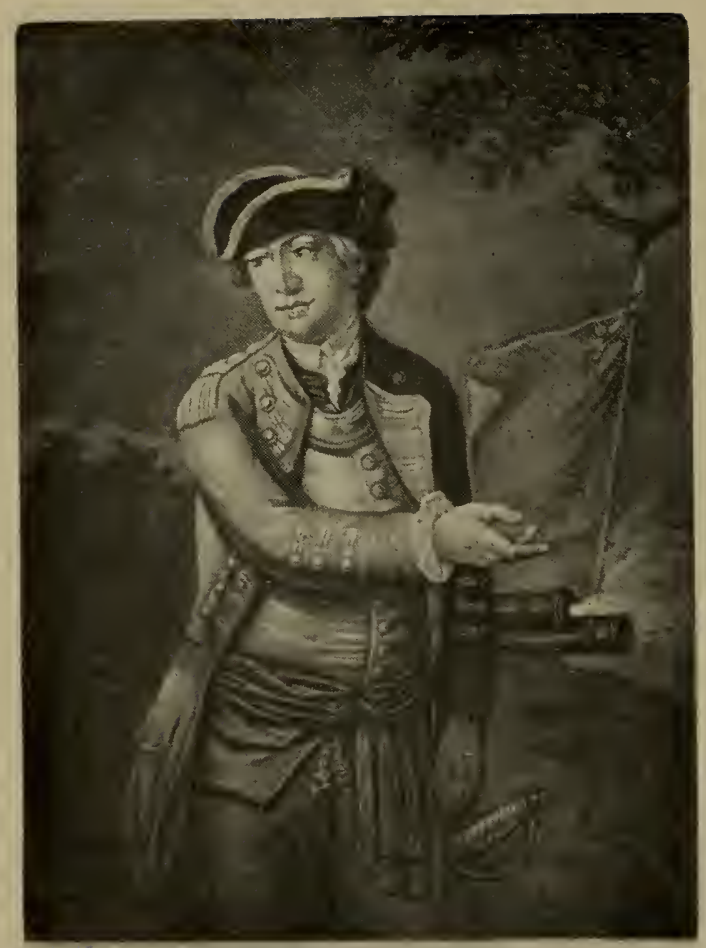

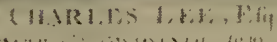

No. 47

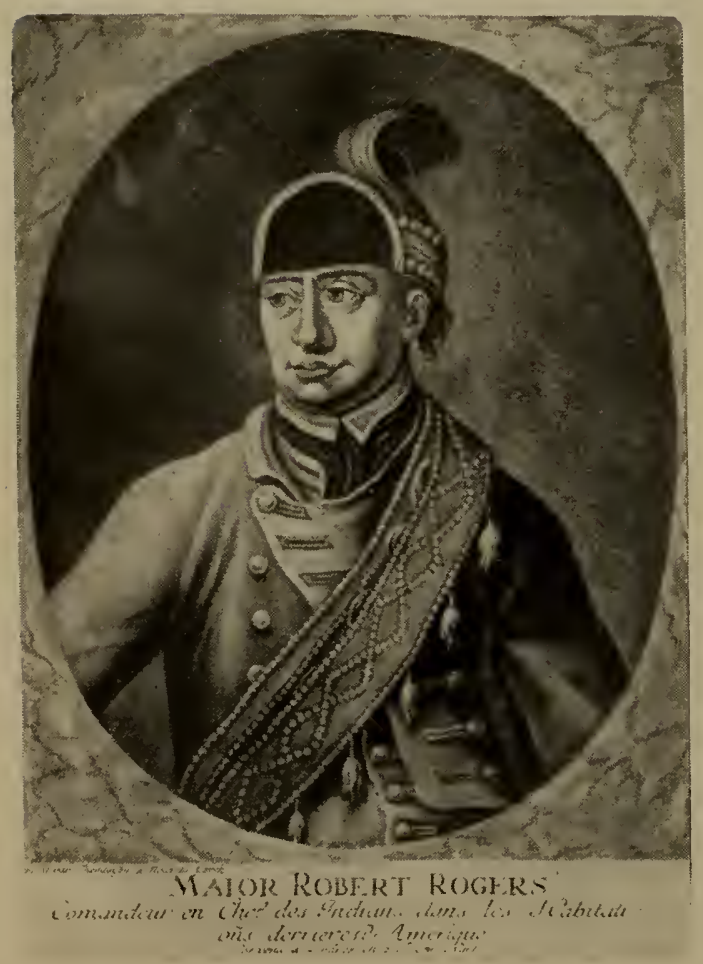

No. 71

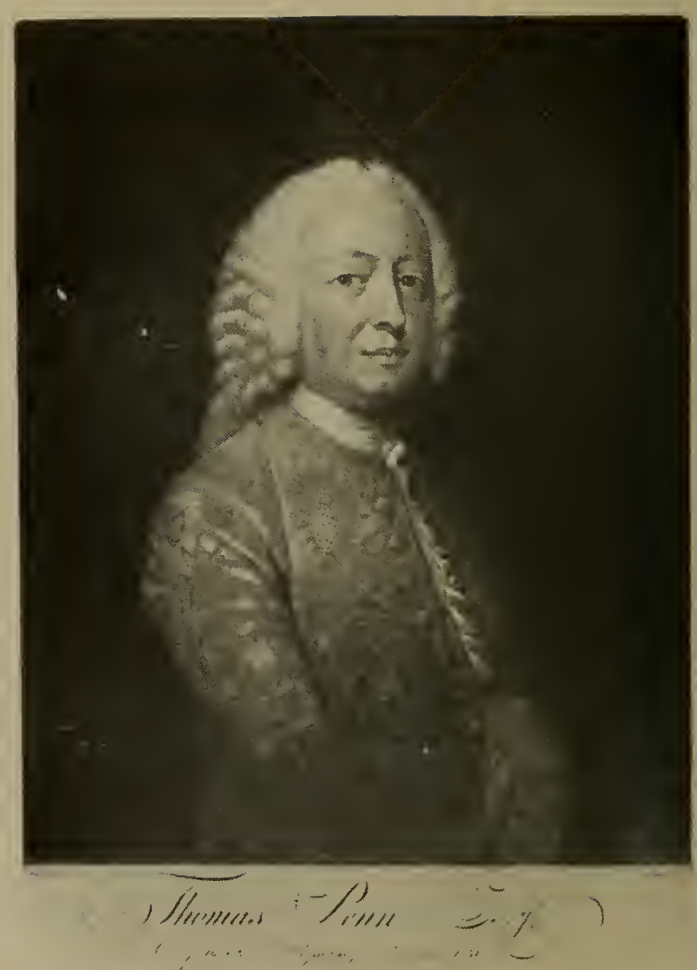

No. 63

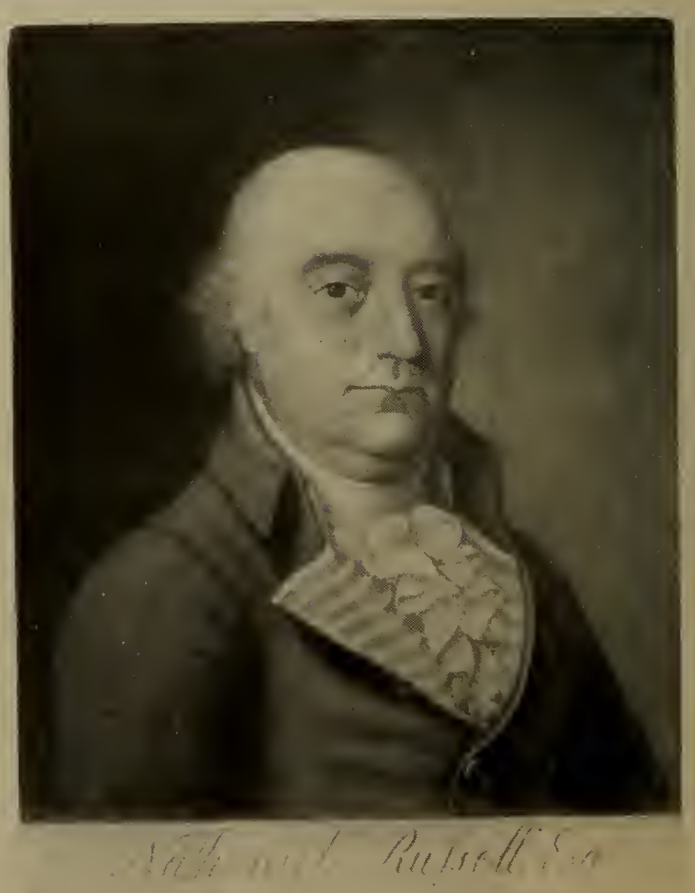

No. 74 


\section{ROOSEVELT, THEODORE.}

"Theodore Roosevelt." Full bust. Face slightly to right. Oval, in ornamental frame work. Etched by Sidney L. Smith. Folio. Boston, 1905. $\$ 20.00$

Artist's signed proof on Japan paper with remarque.

\section{RUSSELL, NATHANIEL.}

"Nathaniel Russell, Esq." Full bust to right. Mezsotint very choicely colored. Designed and engraved by $\mathrm{E}$. Savage. 4to. Boston, about 1780.

The Rarest of all Savage's Portraits. In the choicest possible condition. Very little is known of Nathaniel Russell except that he was one of the American Loyalists who embarked at Boston with the British army for Halifax in 1776.

\section{RUTLEDGE, JOHN.}

"John Rutledge. Chief Justice of the United States Supreme Court, 1795." Full bust to right. After the painting by Robert Hinckley. Folio. New York, 1901. \$7.50 Japan proof.

\section{SHIPWRECK.}

"Loss of the Packet Ship Albion." Fine stipple engraving by C. Tiebout, after T. Birch. Oblong folio. Philadelphia, 1823.

Extremely rare. A very fine colored impression. The Albion with many American passengers was wrecked off the Irish coast April 22, 1822.

\section{STORY, JOSEPH.}

Associate Justice of the Supreme Court and Professor of Law at Harvard. Died in 1845. Bust portrait on parchment etched by James S. King and signed by the artist. Folio. New York, 1902.

$\$ 20.00$

\section{TANEY, ROGER BROOKE.}

Chief Justice of the Supreme Court. Full bust. Face slightly to left. Proof etching on parchment signed by the artist James S. King. New York, $1904 . \quad \$ 20.00$

A splendid proof impression.

\section{8a TAYLOR, ZACHARY.}

Original Life Portrait in oils of General Zachary Taylor by Jesse Atwood, the well known Philadelphia Portrait Painter. In May, 1847, he journeyed to Monterey to paint in oils the portrait of the Hero of Palo Alto; Resaca 
de la Palma, Monterey and Buena Vista. The artist produced a life-like bust portrait of the General in military uniform. Size 20 inches by 24 inches in fine gilt frame of the period. The picture is accompanied by a very characteristic Autograph Letter signed from the Future President to the Artist. It reads: "Head Quarters, Army of Occupation Camp near Monterey, Mexico, May 31st, 1847. Mr. J. Atwood. Dear Sir: Before leaving here on your return home I must tender you my sincere thanks for I fear, the undeserved compliments, you have paid me in the danger, fatigue, labor and trouble you have undergone and encountered in traveling from the City of Philadelphia to this place, for the purpose of painting my portrait, and haing completed the same, THE FIRST EvER TAKen of Me By ANy ARTist, and being about to leai'e us on your return, I take this opportunity of wishing you a safe, speedy and pleasant trip to the Bosom of your Family and Friends, and ruishing you continued health and prosperity, I remain acith considerations of high $R c$ spect and Esteem, your obedient Servant. Z. TAYLOR." The price of the Letter and Portrait is $\$ 2,000.00$

A splendid relic of one of America's Greatest Soldiers and Presidents.

\section{WAITE, MORRISON R.}

"Chief Justice of the United States Supreme Court 1874-1888." After the painting by Adele M. Fassett. Folio. New York, 1901. $\$ 7.50$

Japan proof.

\section{WASHINGTON, GEORGE.}

"Washington and his Mother." Engraved by J. McRae after H. Brueckner. Oblong folio. New York, n. d.

\section{WASHINGTON, GEORGE.}

"General Washington." Full length in uniform. Standing in front of a rearing horse held by his orderly. In the background a spirited view of the Battle of Trenton. Engraved in line by Cheesman after John Trumbull. Folio. London. A. C. De Poggi, 1794.

$\$ 65.00$

Generally considered as the best military portrait of Washington and Trumbull's masterpiece. 


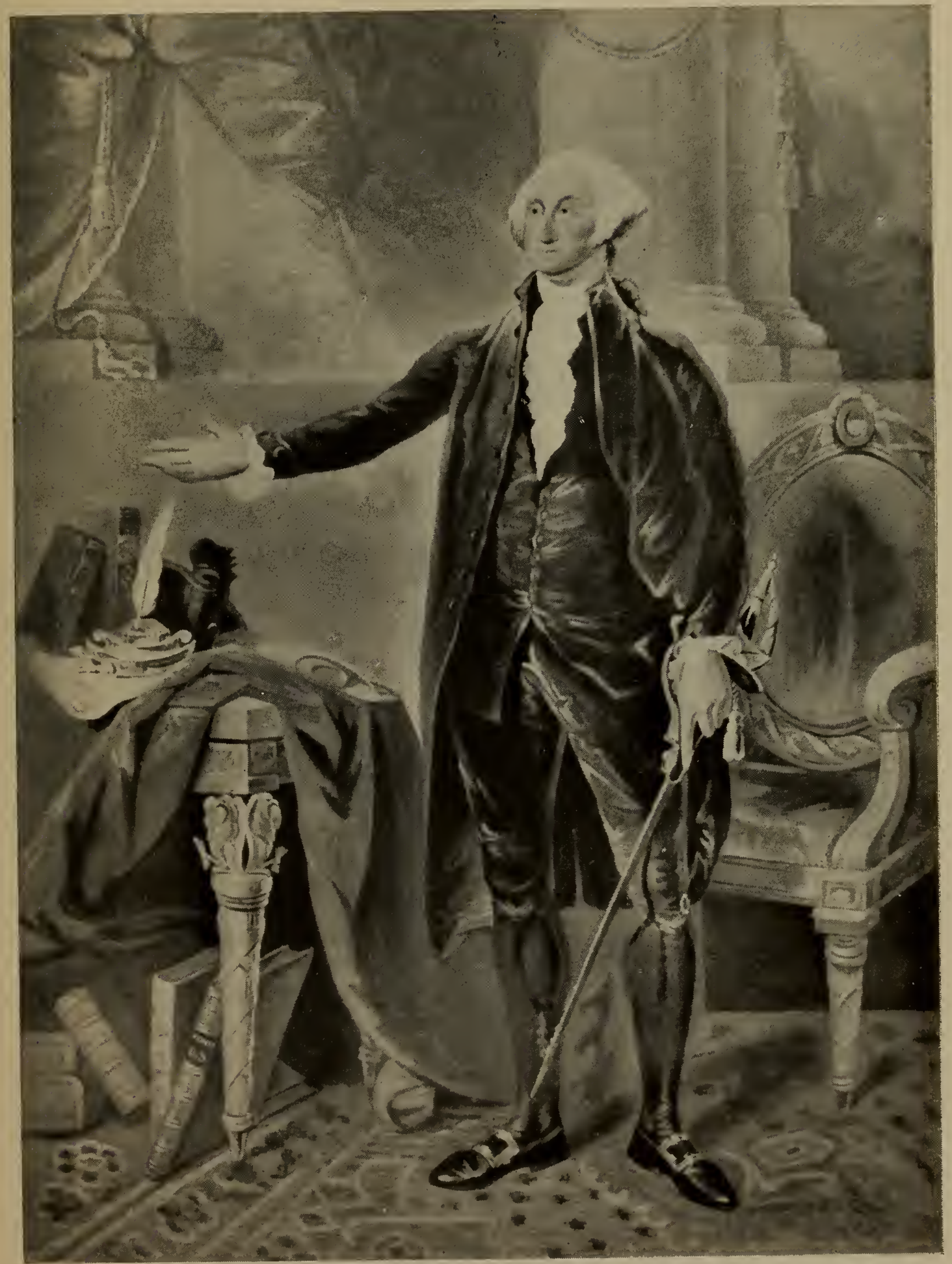

No. 82 
82 WASHINGTON, GEORGE.

"General Washington." Full length standing. Head slightly to left. Right arm extended as if making an address. Dress sword in left hand. To the left a table with books and inkstand. In the background pillars and curtain. Engraved in line by James Heath after Gabriel Stuart. Folio. London. Jas. Heath, 1800.

$\$ 50.00$

The famous Lansdowne portrait.

\section{WASHINGTON, GEORGE.}

"Washington." Full bust in uniform, head to left. Engraied by' Blanchard after Couder. Brilliant open letter, proof on India paper. Paris, 11. d.

A splendid portrait of the Trumbull type.

$\$ 15.00$

S4 WASHINGTON, GEORGE.

"Gen. George Washington." Full bust, almost full face. In miniform with ribbon of the Cincinnati. Oval in rectangle. Engraved by Liebe. 8 vo.

$\$ 22.50$

The very rare Baker No. 55 .

85 WASHINGTON, GEORGE.

"George Washington delivering his Eulogy on Lafayette." Etched by Charles B. Hall from a contemporary painting. 4to. The set of 3 proofs.

Only 35 sets issued.

\section{WASHINGTON, GEORGE.}

In Masonic regalia. Engraved by Charles B. Hall from the original painting by Gilbert Stuart. 4to. The set of 3 proofs.

$\$ 10.00$

Only 35 sets issued.

\section{WASHINGTON, GEORGE.}

Mount Vernon. Fine oil painting of the house at Mount Vernon resided in by George and Martha Washington until their last days. The artist has depicted the front view of the house with its Colonial porch with eight columns as it looks down upon the river in which a goodsized schooner is lying. Both the summer landscape and the architectural features are skilfully executed by some Colonial artist of considerable ability and it is said to have been painted during the last few years of Martha Washington's life. Size $32 \times 23$ in old gilt frame. About 1800. 


\section{WASHINGTON, GEORGE.}

"General Washington." Full length, in uniform, standing on a cliff overlooking a river, pointing to a fortification on the opposite bank. In the background a negro with a horse. At the foot of portrait an Indian holding a shield with the Washington Arms. Engraved In MEZzotint by V. Green After John Trumbull. Large folio. London. V. Green, 1781.

The most attractive and desirable of all Washington portraits for framing purposes.

89 WEBSTER, DANIEL.

"Daniel Webster." Full length, standing face to right. Statue of Washington in background. Mezzotint and line. Boston. R. Andrews, n. d.

$\$ 6.00$

\section{WHITMAN, WALT.}

"Walt Whitman." Fine photogravure. Half length, seated. Facing to right. Japan proof. Folio. New York, 1887.

Autographed by Walt Whitman. Also with presentation inscription to "E. C. Stedman with cordial regards of A. V. S. Anthony."

\section{WILSON, WOODROW.}

Twenty-eighth President of the United States. Half length photograph. Face slightly to left. Size, in oak frame, 15 inches by 12 inches. New York, 1916. \$20.00

With the President's autograph in lower margin.

\section{WOLCOTT, OLIVER.}

"His Excellency, Oliver Wolcott, Governor of the State of Connecticut." Full bust. Head to left. Engraved in line by A. B. Durand after Thomas Sully. Small folio. New York, about 1820.

$\$ 25.00$

\section{WOLFE, JAMES.}

"Commander-in-Chief of His Majesty's Forces in the Expedition against Quebec. Who glorionsly fell, in the Cause of His King and Country, in that signal Victory gained over the French, Sept. 13, 1759. Half length, in uniform, almost full face, to left. Oval in rectangle. Mezzotint. Folio, n. d.

Magnificent Impression of This Excessively Rare Plate and the Most Pleasing Portrait Known of the Hero of. Quebec. 
94 WOLFE, JAMES.

"The Death of General Wolfe." Engraved in line by Wm. Woollett after Benjamin West. Oblong folio. London. Boydell, 1776.

$\$ 35.00$

Scarce.

\section{YORKTOWN.}

"Plan of the investment of York and Gloucester, surveyed and laid down by Sebastian Banman, Major of the Nea "York or 2nd Artillery." Taken between the 22nd and 28th of Octuber, 1781. Finely engraved on copper with handsome scroll at bottom, backed by flags, insignia and military paraphernalia by $R$. Scott. Atlas folio, neatly framed and glazed, size $25 \mathrm{I} / 2 \times 18 \mathrm{I} / 4$ inches. Philadelphia, 1782.

$\$ 175.00$

An Extremely Rare and Important Contemporary RevoluTIONARY MAP, having been issued separately and not taken from a book. Dedicated to "His Excellency, General Washington, Commander-in-Chief of the Armies of the U.S. of America."

Sebastian Bauman, the designer, was distinguished in many ways throughout the Revolution. Beginning as captain in the "German Fusileers," New York, May, 1775, he passed through divers' grades of the service, was in command at West Point, at intervals, 1781-2, and served until June 20, 1784. He was the last to leave New York City when the British took possession, having been left there with only 80 men and 2 howitzers. WHILE at West Point He Prepared Maps of That Post for Washington, and These Papers Also Prepared by Him for Washinton Were Stolen by Benedict Arnold and Afterwards Found in Andre's Boot Upon the Latter's Capture. He Was Present at the Surrender of Cornwallis, and during The Siege of YorkTOWN Drew THE MAP ABOve, which he caused to be engraved at the special request of Washington and of some of his officers. He was, later, colonel in the army and was appointed by Washington the first Federal Postmaster of New York City. He died in 1803.

\section{LINCOLN, ABRAHAM.}

Portrait of Abraham Lincoln. Painted in oil from Life by the Western Artist H. Colcard. Face to right with Beard, grayish blue eyes, black tie. Size 21 inches by 26 inches in a very handsome Rococo Frame. About $1863-4$.

$\$ 3,500.00$

A Superb Oll Painting of Lincoln. Only a very few portraits of him were painted in Lincoln's lifetime and these are all in public institutions. This portrait was formerly in the Libby Prison War Museum where it was seen and much admired by numbers of Lincoln's personal friends and contemporaries. 


\section{LINCOLN, ABRAHAM.}

Portrait of President Lincoln, three-quarter length, seated beside a roll-top desk; face to right. The original crayon drawing by Brady in life size. $64 \times 54$ inches, with frame richly gilt. Washington. 1864 . $\$ 2,500.00$

Unique and extremely fine Lincoln life portrait and considered by Lincoln himself as his very best portrait. It was especially executed in 1864 by Anthony Brady, the famous Civil War photographer and artist at Washington. He rated it as one of his finest works and it remained on exhibition, and not for sale, in his gallery until the opening of the Centennial Exposition in 1876 , where it was placed on view with portraits also by Brady of Grant, Sherman, Thomas and Farragut, all of the same style and uniform in size. At the close of the Exposition Brady again exhibited it at his Washington gallery where it remained till his death.

A Priceless Acouisition to any Public or Private Lincoln Memorial Collection as Having BeEn Drawn Under Lincoln's Own Approval at the Height of His Career and the Finest Portrait of Him Ever Produced.

\section{LINCOLN, ABRAHAM.}

Finely executed crayon drawing touched up with white paint, by the well known Civil War Artist, ALFRED R. WaUd. The scene represents a Reception given by President Lincoln to the Officers of the Army and Cabinet Officers and their Families. Amongst them are the easily recognizable figures of the President, Gen. McDowell, Major Lamon, Colonel Wheeling, Gen. Hinzelman, Secretary Chase and his Daughter, Miss Cameron and Simon Cameron, Gen. Franklin and many others. Size 18 inches x 14 inches. Signed and dated "Alfred R. Waud." 1862. $\$ 250.00$

Unique. Waud was a well known illustrator on Harper's Weekly and other well known New York papers. 








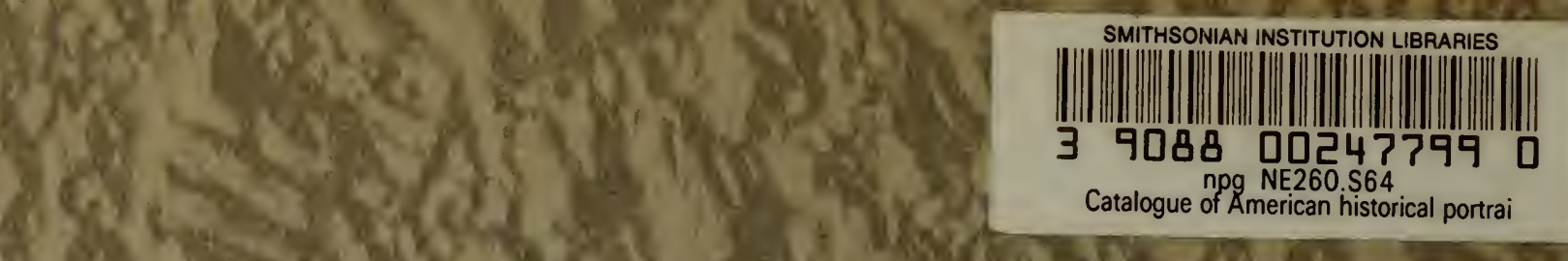

Catalogue of American historical portrai

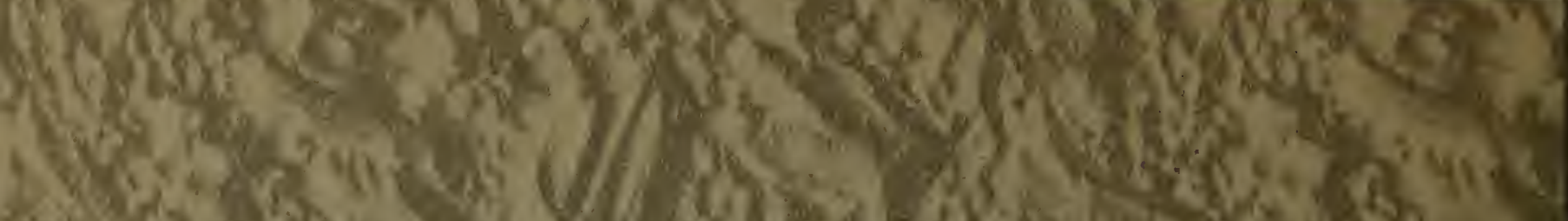

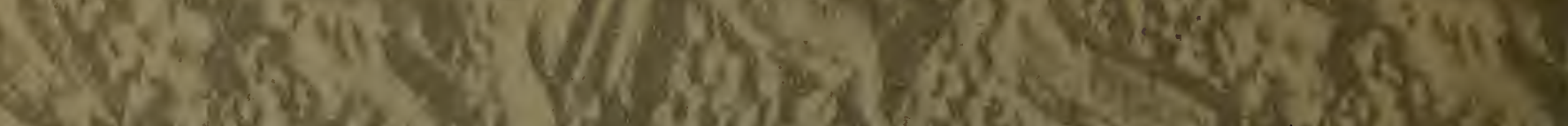

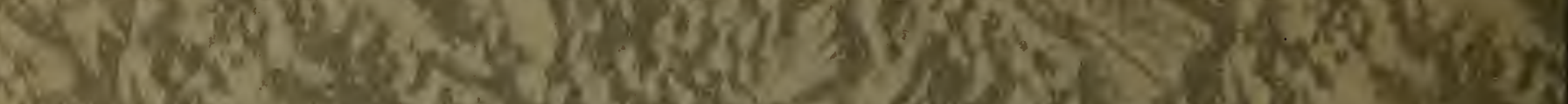

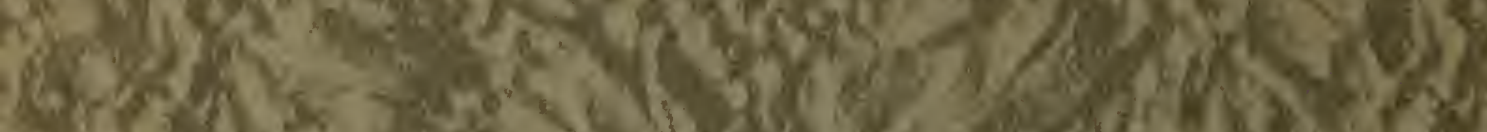

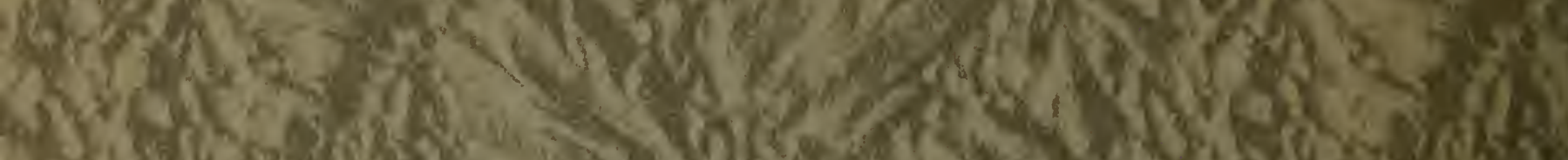

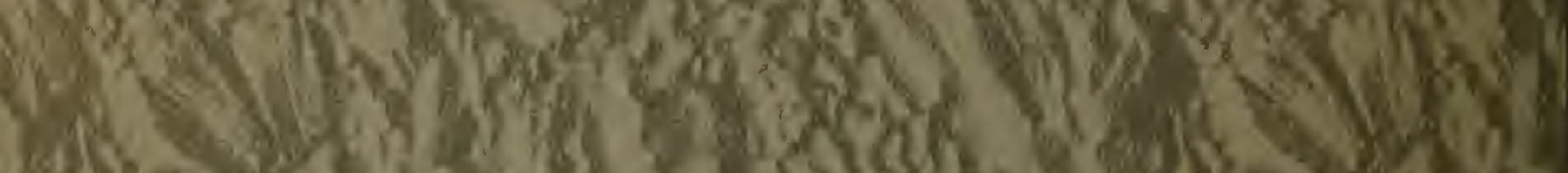

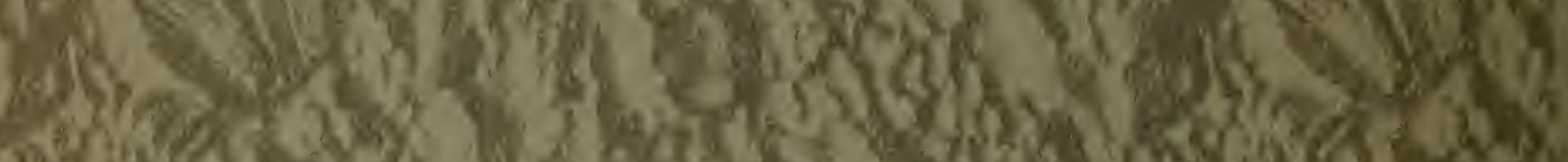

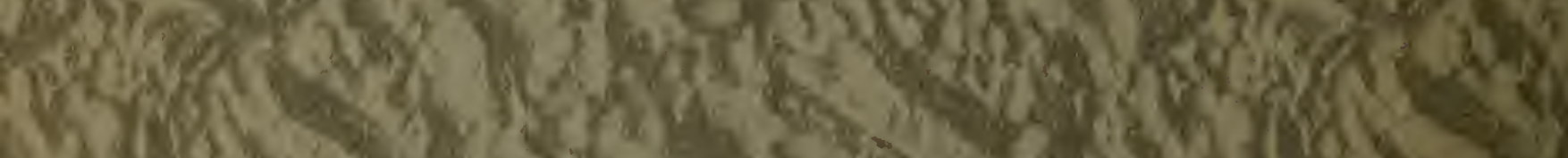
(3)

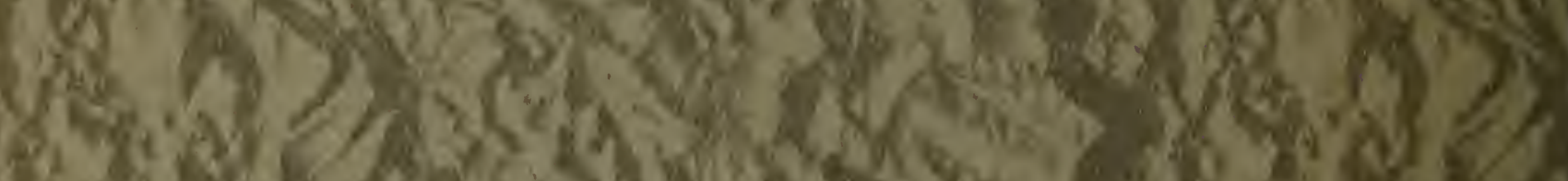

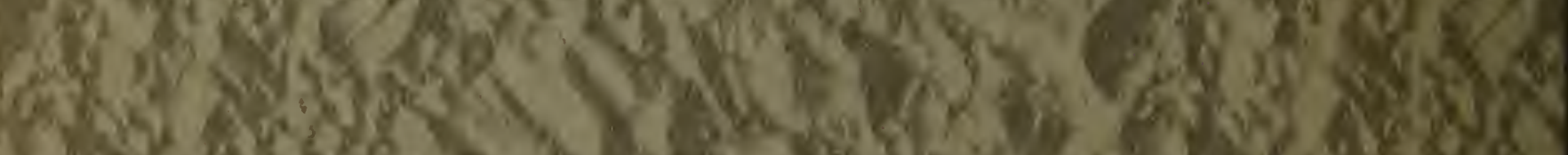

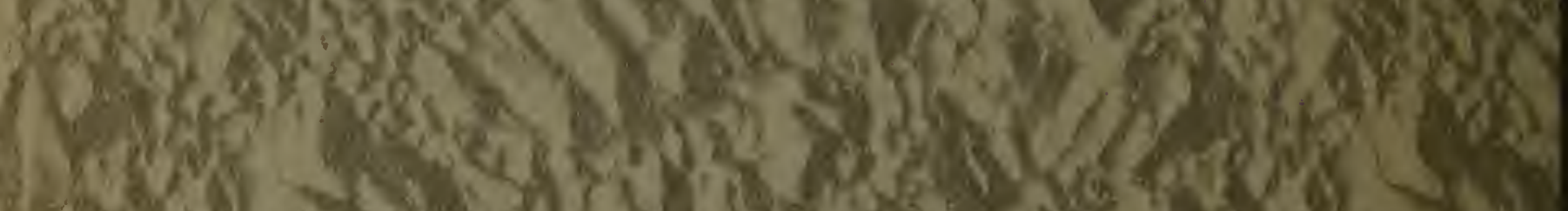

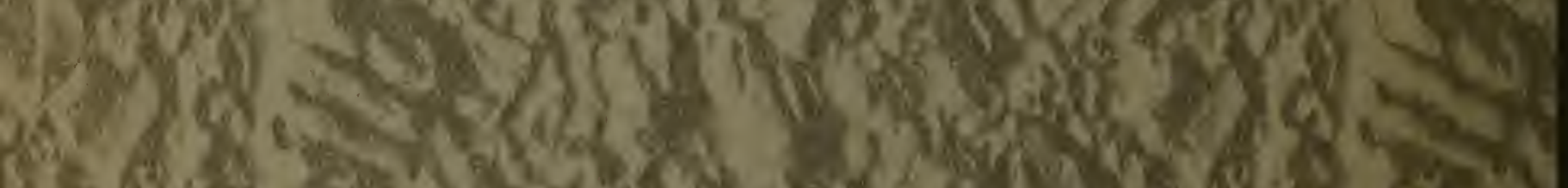

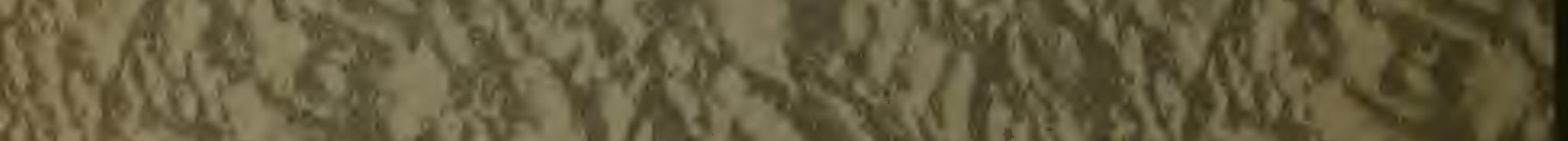

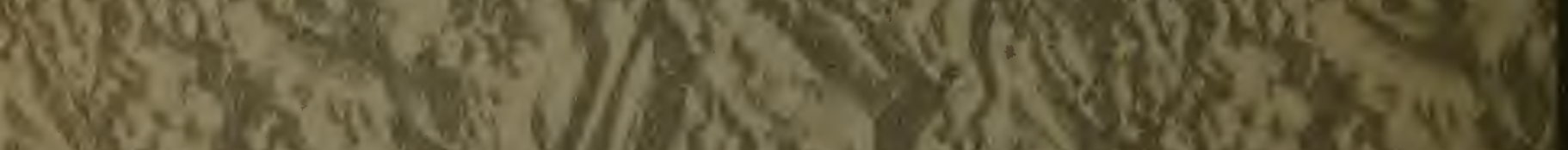

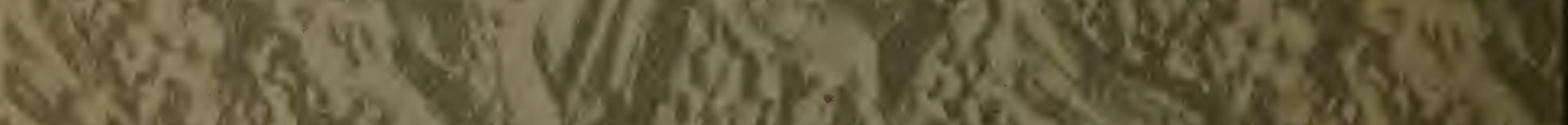

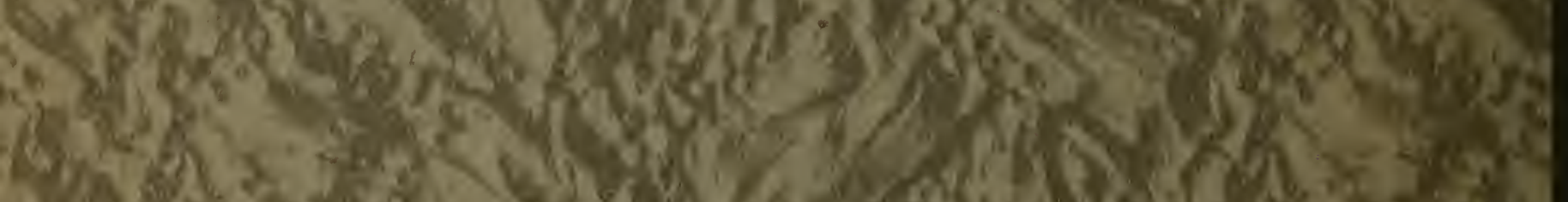

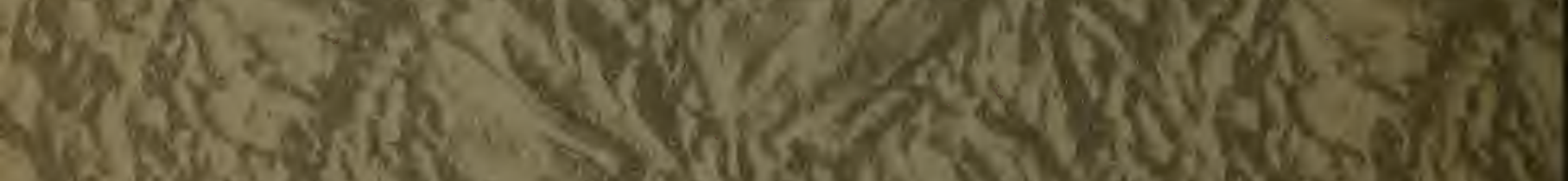

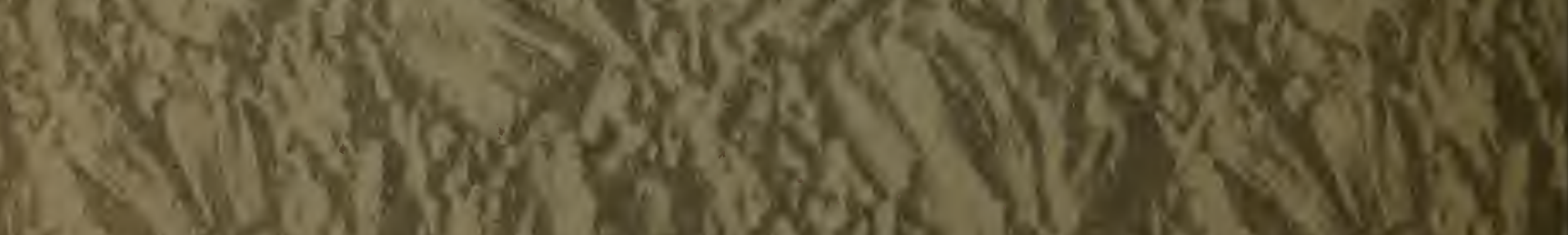

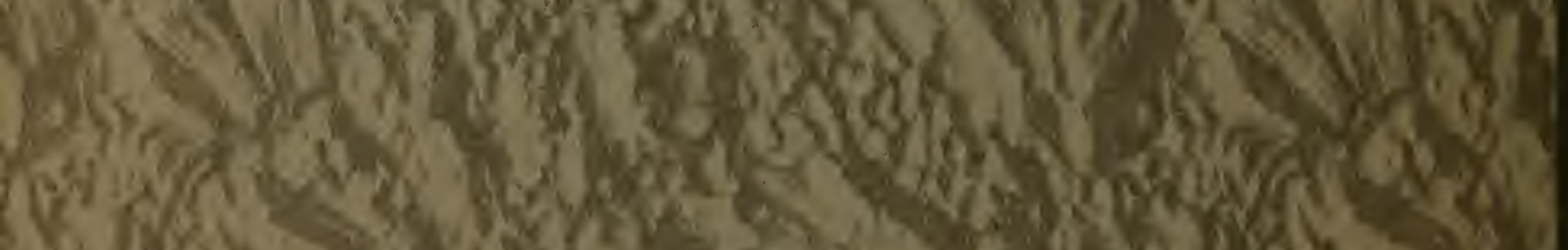

Not.

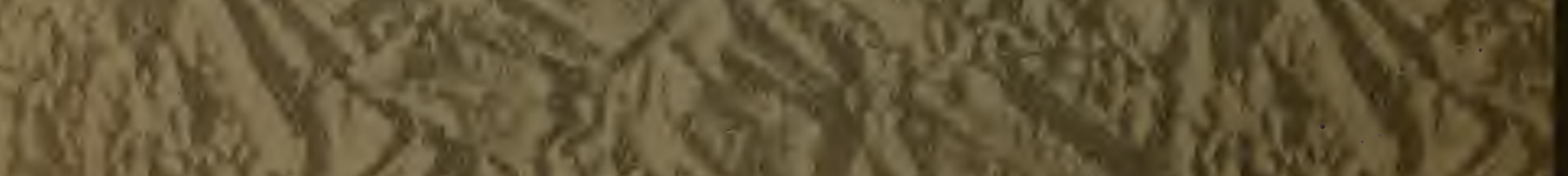

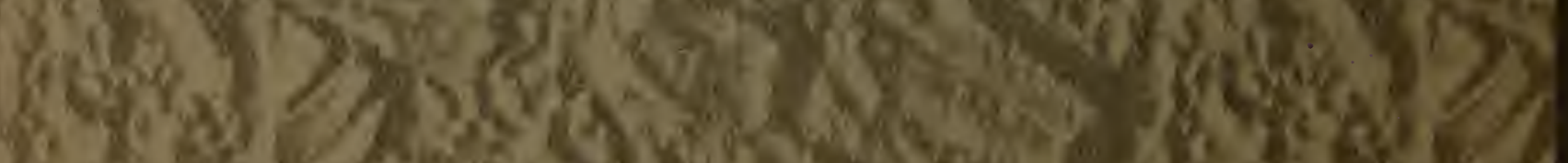

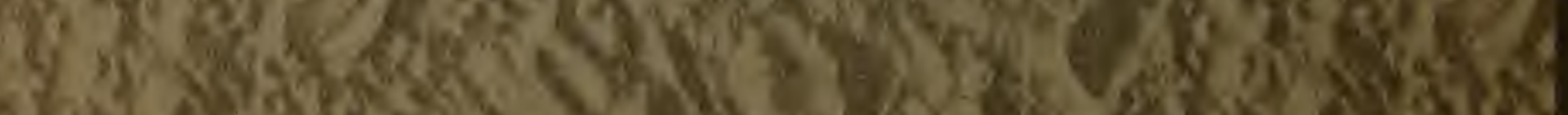

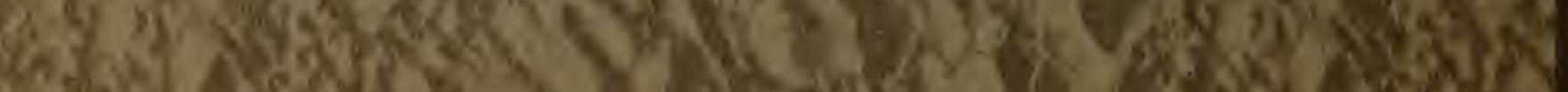

